\title{
LA PASARELA DE LOS DIOSES. El Zeus de Olimpia y el Coloso de RODAS COMO MODELOS ICONOGRÁFICOS DIVINOS EN EL CRISTIANISMO* \\ The catwalk of the gods. The Olympian Zeus and THE Colossus of RHOdes AS DIVINE ICONOGRAPHIC MODELS IN CHRISTIANITY
}

Ainhoa De Miguel Irureta Universidad Católica de Murcia AINHOA_DE_MIGUEL@HOTMAIL.COM

Juan Ramón Carbó García Universidad Católica de Murcia JRCARBO@UCAM.EDU

\section{RESUMEN}

La estatua de Zeus en Olimpia realizada por Fidias y la estatua colosal de Helios en Rodas realizada por Cares de Lindos, dos de las Siete Maravillas de la Antigüedad y las únicas de carácter escultórico, se convirtieron en modelos iconográficos de poder, de majestad y de lo colosal para emperado-

\section{Abstract}

The statue of Zeus at Olympia by Phidias and the colossal statue of Helios at Rhodes by Chares of Lindos, two of the Seven Wonders of Antiquity and the only ones of sculptural character, became iconographic models of power, majesty and the colossal for emperors, for personified abstractions

* Este artículo ha sido realizado en el marco de los trabajos del grupo de investigación Stvdia Hvmanitatis, de la Universidad Católica de Murcia. Agradecemos las aportaciones y sugerencias de los evaluadores anónimos, que nos han permitido mejorar el resultado final. 
res, abstracciones personificadas y también para otros dioses. A través del análisis de estas maravillas, de sus ropajes, atributos, complementos, posturas, tamaño, etc. y de cómo fueron asumidas o cómo influyeron posteriormente tanto para las imágenes del Dios cristiano como para la de emperadores romanos cristianos y emperadores posteriores, pretendemos poner de manifiesto la gran relevancia e influencia religiosa de las representaciones más paradigmáticas de estos dioses a lo largo de dos mil años, gracias a haber "desfilado" en esas pasarelas privilegiadas que constituyeron las diferentes listas de las Siete Maravillas del mundo antiguo. as well as for other gods. We intend to highlight the great relevance and religious influence of the most paradigmatic representations of these gods over two thousand years, thanks to having paraded in those privileged catwalks that constituted the different lists of the Seven Wonders of the ancient world. And we will do it through the analysis of these wonders, its size, clothes, accessories, positions, attributes... and how they were taken or how they influenced the images of the Christian God and the Christian Roman Emperors and later Emperors.

\section{PALABRAS CLAVE}

Zeus, Coloso de Rodas, Siete Maravillas, iconografía, Cristo, modelos, atributos

\section{KEYWORDS}

Zeus, Colossus of Rhodes, Seven Wonders, iconography, Christ, models, attributes 
LA ICONOCLASIA PRESENTE EN EL CRISTIANISMO de los primeros siglos y la progresiva adopción de imágenes simbólicas o incluso de representaciones figurativas de Cristo heredadas de la tradición greco-romana son fenómenos conocidos. De igual forma, la influencia iconográfica de la gran estatua de Zeus realizada por Fidias en Olimpia en el desarrollo de la imagen del Cristo pantocrator también se ha estudiado de forma general, así como la utilización cristiana de algunos esquemas conceptuales e iconográficos de Helios. ${ }^{1}$ En este trabajo pretendemos analizar dichas influencias desde la perspectiva de esos modelos como paradigmas, por formar parte del selectísimo club de las Siete Maravillas de la Antigüedad. En este sentido, las diferentes listas de maravillas del mundo antiguo, en circulación desde finales del siglo II a.C., habrían actuado como verdaderas pasarelas en las que estos modelos, al desfilar por ellas, pudieron potenciar significativamente su fama e influencia en distintos ámbitos. En su momento, el Cristianismo tampoco escapará de estas tendencias: el Zeus de Olimpia y el Coloso de Helios en Rodas acabarán inspirando algunas de las más famosas representaciones del Dios cristiano a lo largo de la historia, desde la Antigüedad Tardía hasta las épocas posteriores e incluso llegando a nuestros días para constituirse en algún caso en nueva maravilla del mundo.

Ya en la primera lista conservada íntegramente, aquella atribuida a Antípatro de Sidón, de finales del siglo II a.C., aparecen en la selección tanto la estatua de Zeus en Olimpia como el Coloso de Rodas, siendo las únicas de carácter escultórico entre las

1. En las próximas páginas iremos planteando cada una de estas cuestiones, con la bibliografía pertinente para cada caso. 
siete. $^{2}$ También del siglo II a.C. fue el ingeniero Filón de Bizancio, bajo cuyo nombre se recoge lo que se ha traducido modernamente como Guía de viaje por las Siete Maravillas del Mundo, si bien se piensa que en realidad podría tratarse de una compilación tardía realizada por un autor desconocido que utilizó el nombre de Filón. ${ }^{3}$ En cualquier caso, en esta selección aparecen de nuevo tanto la estatua de Zeus como el Coloso de Rodas. Estas dos listas van a marcar la pauta general de elaboración de este tipo de compilaciones de maravillas desde aquellos momentos y hasta los albores del Renacimiento, cuando quede establecida una lista canónica, que es la que ha llegado hasta nuestros días, prácticamente idéntica a las dos mencionadas, con la salvedad de incluir el Faro de Alejandría en detrimento de las murallas de Babilonia, quizá porque la ciudad mesopotámica, con sus Jardines Colgantes, ya estaba presente de algún modo con sus maravillas en conjunto.

En los aproximadamente quince siglos que median entre el inicio de este fenómeno de las listas de maravillas y el establecimiento definitivo de la lista canónica, en la que, como apuntábamos, vuelven a estar presentes tanto la estatua de Zeus como el Coloso, pueden encontrarse diferentes menciones de algunas de las maravillas o incluso listas propiamente dichas. Por lo general, las dos estatuas que nos ocupan van a seguir apareciendo en la mayoría de fuentes: en el caso de la estatua de Zeus, en los textos de Calímaco, Propercio, Cicerón, Estrabón, Plinio el Viejo, Epícteto, Higinio, Flavio Josefo, Dion de Prusa, Pausanias, Clemente de Alejandría, Casiodoro, Jorge Cedreno y hasta Adriaen de Jonghe (Hadrianus Iunius) a mediados del siglo XVI; para el Coloso, Polibio, Estrabón, Plinio el Viejo, Sexto Empírico, Higinio, Constantino Porfirogénito, Gregorio Nacianceno, Casiodoro, Gregorio de Tours, Beda el Venerable, Cosme de Jerusalén, Nicetas de Heraclea, Dionisio de Alejandría, Miguel el Sirio, Jorge Cedreno, Nicola de Martoni, Jorge Sanguinatio, Angelo Ambrogini Policiano y Adriaen de Jonghe. ${ }^{4}$ En las fuentes

2. Antípatro de Sidón, Anthologia Palatina IX 58. Junto a la estatua de Zeus y el Coloso aparecen las murallas de Babilonia, los Jardines Colgantes de Babilonia, las pirámides egipcias, el Mausoleo de Halicarnaso y el Templo de Artemisa en Éfeso. Realmente, la lista más antigua que conocemos, aunque de forma fragmentaria, es la contenida en los Laterculi Alexandrini: Papyrus Berolinensis 13044v, col.8, 22 ss.; en el fragmento conservado, que hace alusión a una selección de 7 obras maestras, sólo han quedado las menciones del Artemisión, las pirámides y el Mausoleo.

3. Filón de Bizancio, De septem orbis spectaculis, París, ed. Didot, 1858. Para el texto de Filón y otras listas de autores antiguos, ver Brodersen, 1992. Una panorámica general sobre el fenómeno de las listas de maravillas y sobre las maravillas contenidas en las listas iniciales de Antípatro de Sidón y de Filón de Bizancio, en Brodersen, 2010.

4. En las páginas siguientes haremos referencia explícita a algunas de estas fuentes, cuando ahonden en la descripción de sendas estatuas; para el resto de menciones nos remitimos a Brodersen, 2010. 
cristianas tardoantiguas y medievales que se refieren a las maravillas la estatua del Zeus de Olimpia desaparece o bien es sustituida por otra estatua, la mayoría de las veces, una referencia a Belerofonte. Los autores cristianos tuvieron que enfrentarse al problema de tener que tratar con monumentos de claro sentido pagano (la propia estatua de Zeus, el templo de Artemisa...), por lo que, al igual que el Zeus y Belerofonte, algunas maravillas fueron eliminadas, reemplazadas por monumentos bíblicos (por ejemplo, el Artemisión de Éfeso por el Templo de Salomón) o reinterpretadas en clave cristiana (como las pirámides egipcias y los graneros de José). ${ }^{5}$ Sin embargo, el Coloso de Rodas, aun siendo una imagen de Helios, continuó estando presente en las menciones de esos mismos autores cristianos, siempre denominado Coloso pero generalmente sin aludir al dios pagano, lo cual llevará a que tanto en la Antigüedad como en la Edad Media siga siendo una maravilla "archiconocida". ${ }^{6}$

A la vista de lo anterior, resulta evidente que las maravillas eran muy conocidas dentro del círculo de eruditos y poetas de la Antigüedad y de épocas posteriores, pero la fama de algunas de esas obras y la misma idea de las Siete Maravillas del mundo acabaron siendo de dominio público, como atestigua un grafiti en el anfiteatro de Pompeya en el que un admirador de un gladiador le dedica una loa: "Omnia munera vicisti / Ton hepta theamaton esti" (CIL IV 1111).

El prestigio que adquieren las dos estatuas que nos ocupan gracias al privilegiado escaparate que suponen las listas de maravillas ${ }^{7}$ las convierte en arquetipos conocidos, que serán utilizados como modelos iconográficos de poder, de majestad y de lo colosal para emperadores, abstracciones personificadas y también para otros dioses. Sus ropajes, atributos, complementos, posturas, tamaño, etc. se van a imitar como ejemplos de un modelo perfectamente asumido.

Analizaremos la influencia de ambos modelos en los próximos apartados, pero, ahora bien, ¿cómo llega esta influencia al Cristianismo? Debemos tener en cuenta que, para llegar a sentar la base iconográfica de la figura de Cristo, el Cristianismo partió en cierta manera de la nada. Los cristianos antiguos se encontraron con un problema moral muy relevante en la cuestión del retrato, más que cualquier otra imagen, dado que potencialmente expondría a los fieles a la idolatría. Esta es una de las principales razones esgrimidas para explicar la ausencia de registros de la imagen de

5. Belerofonte, vencedor de la Quimera, sería visto por los autores cristianos como una imagen prototípica de San Jorge matando al dragón.

6. Jorge Cedreno, Synopsis Historion, I, Bonn, ed. I. Bekker, 1838, 299 B.

7. Heckenberg, 2011, p. 190. 
Cristo, de su rostro o su apariencia física. ${ }^{8}$ El Antiguo Testamento contiene diversos pasajes que recogen con claridad meridiana la prohibición de realizar imágenes:

“Tened mucho cuidado: el día en que Yahvé os habló en el Horeb desde el fuego no visteis ninguna figura. No os corrompáis fabricándoos escultura, figura de algún ídolo, imágenes masculinas o femeninas, imagen de algún animal de la tierra, imagen de cualquier ave que vuela por el cielo, figura de algún ser que se arrastra por el suelo, imagen de cualquier pez que vive en las aguas debajo de la tierra. Al alzar tus ojos al cielo y ver el sol, la luna, las estrellas y todo el cortejo celeste, no te dejes arrastrar hasta prosternarte ante ellos y darles culto" (Dt. 4, 15-19).

"No tendrás ídolos, no te harás figura alguna de las cosas que hay arriba en el cielo o aquí debajo en la tierra ni de lo que hay en las aguas debajo de la tierra. Ante ellas no te hincarás ni les rendirás culto; porque yo, Yahvé, soy tu Dios" (Dt. 5, 8-9).9

Por lo general, las autoridades eclesiásticas de los primeros siglos de existencia del Cristianismo manifestaron su rechazo a las imágenes. Las actas del Concilio de Elvira (c. 300) recogen en su canon 36 la prohibición de pintar en los muros de las iglesias lo que se venera y adora. Por otra parte, a comienzos del siglo IV, el obispo Eusebio de Cesarea incluso llega a fundamentar con la teología su oposición a las imágenes de Cristo, apoyándose en su doble naturaleza: como Dios, resulta invisible, y como hombre, no podría ser objeto de representación porque su carácter divino absorbe el humano. ${ }^{10} \mathrm{Y}$ sin embargo, también reconoce la existencia de imágenes cristianas. ${ }^{11}$ En el transcurso del siglo IV pueden encontrarse diversos testimonios en la patrística y en otros escritos cristianos que hacen referencia a la existencia de representaciones cristianas como algo habitual. ${ }^{12}$ Las primeras serán signos o símbolos, como la paloma, el pez, el ave fénix, el crismón, el ancla o el cordero. ${ }^{13}$ Las representaciones humanas se centrarán en la figura del Buen Pastor, imagen que se asocia con Hermes Crioforos, dios de los pastores y protector de los rebaños, mostrado como un joven imberbe de cabellos cortos, con túnica por encima de la rodilla, y el carnero sobre los hombros. Puede observarse que las concepciones religiosas de las primeras

8. Grabar, 1985, pp. 66-67.

9. Otros ejemplos en Ex., 20, 4-5; Lv., 26, 1.

10. Eusebio, Ep. a Constancia PG 20, 1545-1549.

11. Eusebio, Hist. Eccl. 7, 18.

12. Errázuriz y Balbontín, 1999, pp. 112-113; Sotomayor, 2003, pp. 870-872;

13. Errázuriz y Balbontín, 1999, pp. 105-108. 
comunidades cristianas, aunque esencialmente judías, se desarrollan arropadas por la cultura clásica greco-romana. Las representaciones que se encontraban en tumbas paganas, incluyendo aquellas que hacían referencia a personajes mitológicos, fueron "cristianizadas" utilizando la misma iconografía para hacer mención de algún pasaje del Evangelio, adquiriendo así una nueva connotación. Esta figuración indirecta aparece también en la figura de Orfeo, cuya visión cristianizada desciende al infierno a liberar a las almas prisioneras, ${ }^{14}$ y en el Sol Salutis, con la apropiación de la imagen del Sol-Helios pagano para su utilización como cristiana - Cristo-Helios -, en un intento de reivindicar a Cristo como "sol verdadero", en contraposición al culto de Sol Invictus. ${ }^{15}$ No obstante, no se encuentran representaciones directas del rostro de Cristo. El joven imberbe que se nos muestra en los tipos mencionados anteriores al siglo IV responde a las costumbres de la época y a las imágenes tradicionales que realizaban los artistas para temas no religiosos. Según Paynes, "durante siglos se le representó como un joven de unos dieciocho años, cara redonda, grandes ojos negros, labios pequeños, con la negra cabellera cayendo hasta los hombros y peinado por delante hasta media frente. A veces sus cabellos son rojizos y muy rizados..." ${ }^{16}$

La actitud cristiana contra las imágenes de dioses paganos, y el peligro de la idolatría, que ya comentamos anteriormente, se materializan en varios edictos contra la idolatría, publicados en el Codex Theodosianus, que prohíben rituales e imaginería. ${ }^{17}$ Sin embargo, en el mismo momento, algunos autores cristianos comienzan a apreciar y valorar el arte y la estética, como es el caso del poeta y rétor Ausonio, que apreció estatuas famosas como la Afrodita de Cnido de Praxíteles y alguna obra de Mirón. ${ }^{18}$ Un ejemplo aún más significativo de este cambio de tendencia lo encontramos en Agustín de Hipona, que conecta la armonía del cuerpo con la belleza del alma, haciendo alusión de este modo al Canon de Policleto. ${ }^{19}$ En general, a finales del siglo IV los autores cristianos comenzaron a mostrar un punto de vista más positivo sobre obras

14. Di Bernardino, 1991, p. 1706; Errázuriz y Balbontín, 1999, pp. 108-111.

15. Errázuriz y Balbontín, 1999, p. 111.

16. Paynes, 1974, p. 214.

17. Cod. Theod. 16, 10, 12; 16, 10, 12, 2; 16, 10, 19, 1-2.

18. Stirling, 2005, pp. 139-141, pp. 148-153. No obstante, también existe la posibilidad de que Ausonio centrase su interés más bien en otros textos previos sobre obras de arte y en aportar su punto de vista en el debate sobre el poder de la imagen y de la palabra; de este modo, este tipo de manifestaciones podrían ser entendidas como parte de una formación cultural y retórica compartida por cristianos y paganos, más que como expresiones de un verdadero interés en las representaciones artísticas en sí mismas. En cualquier caso, las dos formas de entenderlas no son necesariamente excluyentes.

19. Agustín, De vera religione XXIX 55; XLI 77. Ya Orígenes, en el siglo III, se refería a Fidias y a Policleto como maravillosamente perfectos en su arte (Contra Celsum VIII 17), manifestando una va- 
de arte famosas de la herencia cultural greco-romana, coincidiendo en el tiempo con la declaración del Cristianismo como religión oficial del Imperio. ${ }^{20}$

Precisamente esta herencia cultural fue penetrando en el marco cristiano durante los siglos siguientes de la Antigüedad Tardía y el ideal de belleza enriqueció la visión cristiana sobre la estética y mejoró el desarrollo del arte cristiano. Tal y como ha apuntado Karivieri, "dado que la belleza funciona como vehículo para elevar el alma y su conciencia de Dios, la creación de una obra de arte es entendida como una innovación compatible con la imitación de lo divino, que implica no sólo la imitación de la naturaleza sino de la idea que uno tiene del objeto bello e inteligible. La obra de arte crea así un vehículo para el alma para lograr una mejor comprensión de Dios y de la belleza divina". ${ }^{21}$

A la luz de lo dicho, vemos, pues, que las dos famosísimas obras de arte a las que nos estamos refiriendo, representaciones de dioses griegos que formaban parte de las Siete Maravillas del mundo, realizadas por artistas de la talla de Cares de Lindos - discípulo de Lisipo - y sobre todo, Fidias, se encontraban en esos momentos en una posición inmejorable no sólo para ser valoradas positivamente dentro del Cristianismo sino para convertirse en modelos iconográficos para el arte cristiano. Cuándo, de qué manera, en qué condiciones y con qué resultados son interrogantes a los que intentaremos dar respuestas a continuación.

\section{El Zeus de Olimpia}

Resulta sorprendente que, tratándose de una estatua de tal fama, no haya llegado hasta nuestros días ninguna copia ni representación detallada, aunque conocemos la descripción pormenorizada realizada por Pausanias ${ }^{22}$ y disponemos de algunas

loración personal que se hace eco de la apreciación general de las obras artísticas de estos escultores en época imperial, aun cuando su principal interés no sea el realizar un estudio estético.

20. Karivieri, 2016, pp. 204-205.

21. Ibidem, pp. 207-208. Dentro de la corriente neoplatónica del momento, volvemos a encontrar cierto paralelismo con el concepto de belleza de Platón, que describe el concepto original de esplendor según el cual la belleza reside en una suerte de luz ininteligible de la cual el mundo sensible es una mera aproximación. Para Platón, la belleza es algo independiente de lo físico, por lo que no tiene que corresponderse con una imagen visual, y la belleza que encontramos en el mundo material tiene su origen en la "idea de belleza". Esta teoría aparece en diversas obras como son los diálogos del Timeo, Hipias Mayor, Fedro o el Banquete. Ver supra notas 53, 54 y 55.

22. Pausanias, Descipción de Grecia V 11, 1-8 (trad. Ma.C. Herrero, Madrid: Gredos. 1994). 
monedas de época de Adriano que nos proporcionan una idea general. ${ }^{23}$ Por medio de estas fuentes podemos recomponer la figura: Zeus aparece sentado y erguido en su trono, con barba y cabellos largos trenzados alrededor de su cabeza y ceñidos por una corona de olivo, vestido con un himatión directamente sobre el cuerpo, sin quitón debajo, con un pliegue sobre el hombro izquierdo que deja el hombro desnudo; en la mano izquierda sostiene un cetro coronado por un águila, mientras que con la mano derecha extendida sostiene una Niké. ${ }^{24}$ El trono estaba adornado con atributos y mitos para la celebración de su poder. Los pies del dios reposaban en un escabel con leones dorados, que mostraba la Amazonomaquia de Teseo. Todo el conjunto estaba dispuesto sobre una base en la que estaba representado el nacimiento de Afrodita ante la mirada de los dioses: $:^{25}$

"El dios está sentado en un trono y está hecho de oro y marfil. En la cabeza tiene colocada una corona que imita a un ramo de olivo. En la mano derecha porta una Niké igualmente de marfil y oro, que tiene una cinta y sobre la cabeza lleva una corona. En la mano izquierda del dios hay un cetro adornado con todo tipo de metales. El ave posada sobre el cetro es el águila. De oro también son las sandalias del dios e igualmente su túnica, en la que se han representado animalillos y flores de lirio.

El trono es colorido por el oro y las piedras, y colorido por el ébano y el marfil. También se han pintado sobre éste elaboradas representaciones de animales y figuras. Cuatro Nikés en actitud de bailar están representadas una en cada pata del trono, y otras dos más al pie de cada pata. [...] Entre las patas del trono hay cuatro rodapiés, que van de una pata a otra. En el rodapié justo frente a la entrada hay siete figuras, pues nadie sabe de qué modo desapareció la octava de ellas. Éstas serían representaciones de competiciones antiguas, pues en tiempo de Fidias aún no se habían instituido las competiciones de muchachos. Dicen que precisamente el que se está atando una cinta a la cabeza se parece a Pantarques. Éste era un joven eleo que fue querido de Fidias [...].

Aunque sé que ya se han registrado las medidas del ancho y alto del Zeus en Olimpia, no voy a alabar a los que las tomaron, pues incluso las medidas que dieron quedan muy lejos de la impresión que reciben quienes contemplan la estatua. No, el mismo dios, según la leyenda, dio fe del talento artístico de Fidias. Para cuando la imagen estuvo

23. Se trata de monedas procedentes de Elis, actualmente en Florencia (Arch. Mus. Inv. 36065) y Berlín (Münzkabinett Inv. 18200646).

24. Pausanias, V 11, 1.

25. Pausanias, V 11, 7. 
prácticamente terminada, Fidias rogó al dios que le mostrase con una señal si el trabajo era de su agrado. Inmediatamente, cuenta la leyenda, un trueno cayó sobre la parte del suelo en la que hasta hoy en día permanece la jarra de bronce que cubre el lugar".

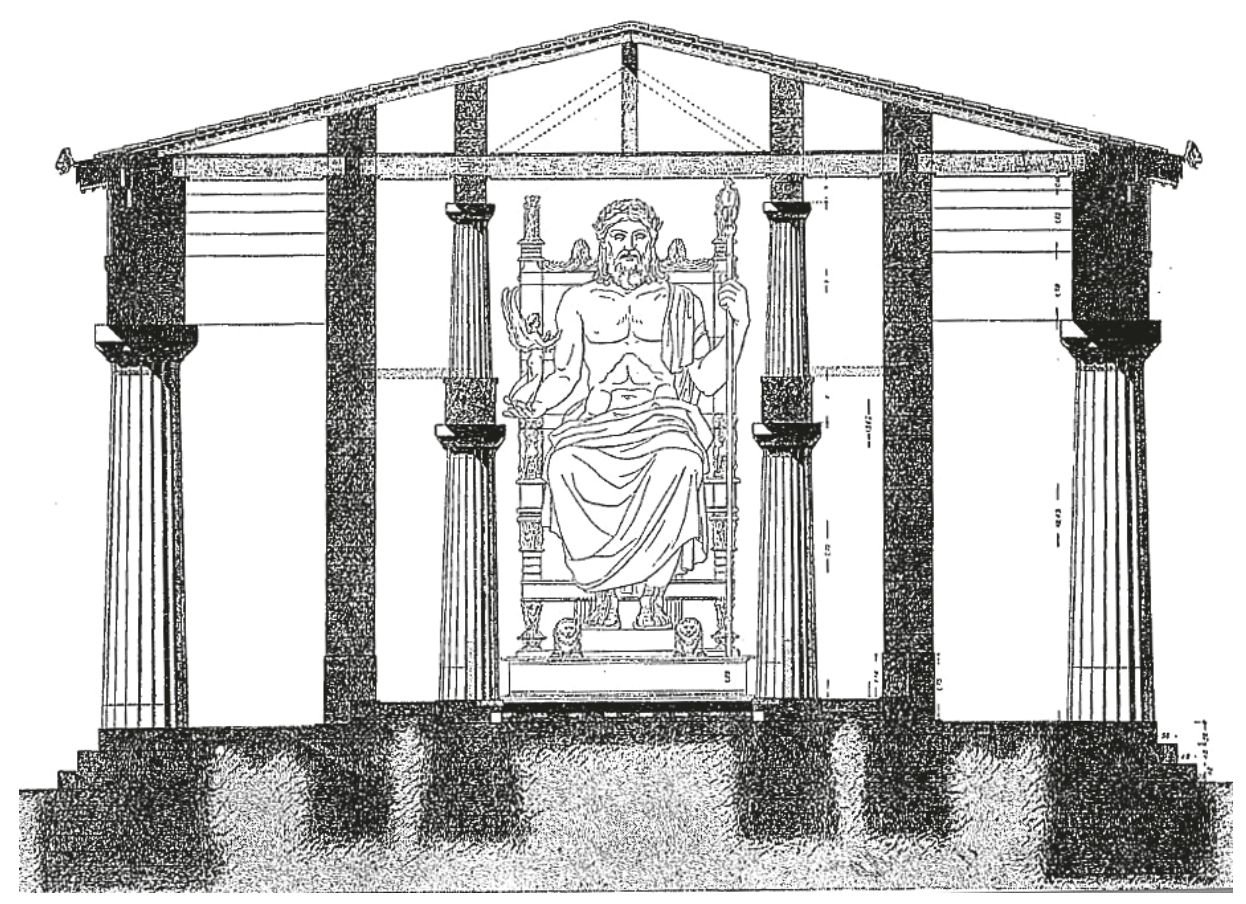

Fig. 1. Reconstrucción del Zeus de Fidias por F. Adler, en Barringuer, 2015, p. 21 (Licencia de dominio público de Wikimedia Commons).

Esta es, sin lugar a dudas, la descripción antigua más detallada de una obra de $\operatorname{arte}^{26}$ y como tal, un ejemplo perfecto de ekphrasis, la retórica de la descripción de esculturas y pinturas, muy importante para dotar al lector de una experiencia de creación o recreación de una imagen artística en su imaginación. Sin embargo, el propio Pausanias plantea que el lenguaje descriptivo y las medidas por sí mismas no serían adecuados para transmitir verdaderamente el efecto numinoso del Zeus. Socavando de alguna manera la confianza de los lectores en una comprensión de la estatua a través de

26. Brodersen, 2010, p. 84. 
su descripción, Pausanias en realidad está alimentando en ellos el deseo de contemplarla por sí mismos. ${ }^{27}$ Para la mayoría de fuentes antiguas, el resultado de la contemplación de la estatua no es sólo un gozo estético, sino que tiene también un efecto religioso poderoso en los espectadores. Pollitt apuntaba que un análisis muy exhaustivo distorsionaría el efecto principal de la imagen, que denominaba "sentimiento olímpico", esto es, el sentimiento de ambiente cercano a los dioses olímpicos, conscientes de la condición humana, pero sin vínculos emotivos con ella. "Son las descripciones literarias sobre el efecto del Zeus, y no la descripción objetiva de Pausanias, las que más nos acercan a él". ${ }^{28}$ Por su parte, Platt, más recientemente, asegura que "respuestas repetidas sugieren que (las estatuas de Fidias) se presentan ante los espectadores a lo largo de la Antigüedad como la quintaesencia de la manifestación material de la deidad". 29 A este mismo respecto, Davison ya recogía un epigrama de la Antología Palatina que hacía referencia al realismo y la perfección de la estatua: ${ }^{30}$ "Una de dos, o el dios ha bajado del cielo a la tierra para mostrarte su imagen, Fidias, o tú has subido para ver al dios". ${ }^{31}$

La primera impresión al entrar en el templo de Zeus y hallarse frente a la estatua sería una epifanía. Las estatuas crisoelefantinas no sólo pretendían evocar lo divino sino "reproducir un encuentro divino" ${ }^{32}$ La frontalidad del Zeus colocaba al cultor en una confrontación directa con la deidad, uniendo el esplendor y el temor de lo divino con su tamaño y su poder intimidantes. También se manifestaban en la estatua los efectos habitualmente presentes en la mitología griega cuando los dioses se revelaban ante los mortales, un tamaño inmenso y brillando con luz propia: pese a estar sentado en su trono, la cabeza del Zeus casi rozaba el techo; ${ }^{33}$ los cabellos y barba, y las vestimentas de oro, como también el cuerpo de marfil, brillaban en la ténue luz y se reflejaban en la piscina... ${ }^{34}$ Todo ello tenía un impacto extraordinario causado por la conjunción de los elementos estético-artísticos con los religiosos, tal y como apuntaba Burkert. ${ }^{35}$

La función de sus atributos es definir y amplificar la identidad divina del Zeus (Zeus Olympios). Los dos más característicos son el águila y el rayo; pero en el Zeus

27. Burton, 2015, p. 85.

28. Pollitt, 1987, p. 89.

29. Platt, 2011, p. 87.

30. Davison, 2009, p. 916.

31. Antología Palatina. 2. Filipo de Tesalónica, 480 (trad. Guillermo Galán; Madrid: Gredos. 2004).

32. Platt, 2011, p. 89.

33. Estrabón, Geografía VIII 3, 30 (trad. J.L. García Ramón, J. Gracía Blanco, J. Vela et al., Madrid: Gredos. 1991): “... a pesar de hacerla sedente, la cabeza casi toca el techo, de modo que da la impresión de que si se alzara y se pusiera derecha levantaría el techo del templo...."

34. Lapatin, 2001, pp. 83 y 85.

35. Burkert, 1988, p. 39. 


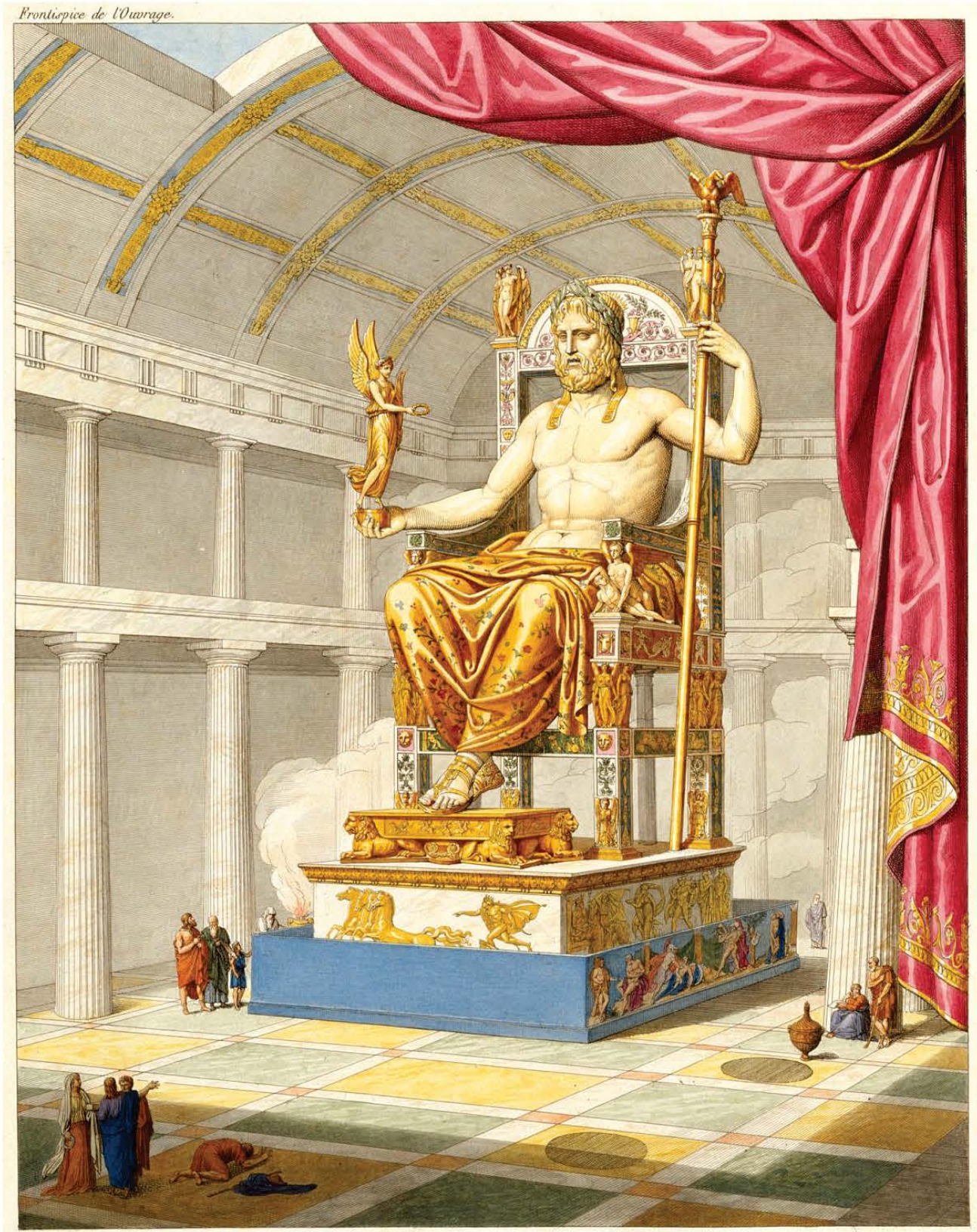

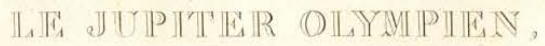

VU DANS SON TR ONEE ET DAYS HIINTERIEUR IDE SON TEMPLE. 
4 Fig. 2. Quatremere de Quincy. 1815. Le Jupiter olympien, ou l'Art de la sculpture antique considéré sous un nouveau point de vue, ouvrage qui comprend un essai sur le goût de la sculpture polychrome, l'analyse explicative de la toreutique et l' histoire de la statuaire en or et en ivoire, chez les Grecs et les Romains..., de Bure Frères, Paris. Portada (Licencia de dominio público de Wikimedia Commons).

de Olimpia, el águila aparece coronando el cetro, que denota su carácter soberano y su supremacía, y el rayo es sustituido por una Niké. Si bien el cetro puede ser atributo de otros dioses, el águila era exclusiva de Zeus entre los dioses olímpicos. La presencia de la Niké y el trono vienen a sumarse a ese cetro con el águila y enfatizan la supremacía del dios en todos los ámbitos. ${ }^{36} \mathrm{El}$ rayo, que habitualmente se presentaba como expresión de su fuerza, de su poder, de su brusquedad y carácter irresistible, así como de su diké - su justicia divina -, no aparece en la estatua de Fidias, sustituido por la Niké, quizás un atributo más adecuado para una estatua sedente entronizada. ${ }^{37}$ Efectivamente, el trono le proporciona su pose estática a la vez que fortalece su imagen como soberano: su efecto es suavizar el carácter de Zeus y reflejar su majestad. Los atributos del dios proporcionaban un lenguaje religioso compartido de manera que cualquiera pudiera reconocerle situándolo en el marco de su propio contexto religioso. ${ }^{38}$

La iconografía de un Zeus sentado no era desconocida en el arte griego, pero supuso un cambio significativo en Olimpia, como ha señalado Barringer, para la que el Zeus de Fidias se sentaba solo, interviniendo únicamente para otorgar la victoria, personificada por la Niké en su mano derecha. ${ }^{39}$ Lo que podría explicar el cambio del tipo de representación de Zeus en Olimpia hacia una figura sentada como juez o árbitro sería un desarrollo histórico-político que significaría un nuevo papel para el dios: distintos especialistas entienden la implementación del arbitraje en Olimpia como consecuencia directa de las Guerras Médicas y en concreto, de la victoria de Platea, que habría inspirado precisamente dicho arbitraje para evitar los enfrenta-

36. Burton, 2015, pp. 93-94.

37. Dowden, 2006, p. 26: describe este cambio como algo más sofisticado y moderno que el rayo. Burton 2011, pp. 51-60, considera que niké y diké son inseparables e interdependientes. Para Barringer, la existencia de la Niké en la mano del Zeus remarca el significado de victoria en la estatua, tanto militar como en el aspecto de las competiciones olímpicas (Barringer, 2011, pp. 61-63).

38. Burton, 2015, p. 81.

39. Barringer, 2015, p. 28. Sobre las representaciones de Zeus entronizado, ver Vlizos, 1999. 
mientos internos entre los griegos. ${ }^{40}$ La razón por la que Zeus no habría funcionado como una deidad políada se debe a su autoridad; si fuera usado por un grupo social en particular, rompería el equilibrio entre facciones sociales competidoras, de modo que más bien aparece para arbitrar el equilibrio entre ellas dentro de la misma polis. ${ }^{41}$ El epíteto Olympios que habría llevado el Zeus de Fidias respondería, así pues, a la naturaleza panhelénica del santuario de Olimpia. ${ }^{42}$

En la elección de los atributos de Zeus para su estatua en Olimpia, Fidias tuvo que actuar cuidadosamente, y a la vista del importante papel que ésta habría de desempeñar en la iconografía posterior, es evidente que tuvo éxito. ${ }^{43}$ De hecho, se consideró, como hacía por ejemplo Quintiliano, que había añadido algo a las formas previas de vivencia y percepciones de lo religioso:

"Sin embargo, se dice de Fidias que tuvo más habilidad para hacer las estatuas de los dioses que las de los hombres; $y$ en las estatuas de marfil no tuvo competidor, aun cuando no hubiera hecho otra cosa que la estatua de Minerva que hizo en Atenas, y la de Júpiter Olímpico que hizo en Élide, cuya hermosura parece que aumentó algún tanto la devoción que ya tenían; en tanto grado igualaba la majestad de la obra a la de aquel Dios".44

En ese sentido, lo que consiguió Fidias fue convertir la idea homérica de los dioses en algo físico, y a partir de ese momento, las imágenes antiguas, aunque en ningún caso se puede considerar que quedasen obsoletas, ya no fueron completamente adecuadas. ${ }^{45}$ Dion de Prusa proporciona una pista para poder entender las palabras de Quintiliano, cuando afirma:

"Quienquiera que tuviera el alma abrumada de tristeza, habiendo soportado muchas penalidades y desgracias en su vida y sin ser nunca capaz de conciliar un sueño tranquilo, hasta este hombre, ante esa imagen olvidaría todas las cosas terribles y duras que han de sufrirse en la vida humana" ${ }^{36}$

40. Vlizos, 1999, pp. 29-30; Sinn, 2004, p. 80; Kyrieleis, 2011, p. 110.

41. Linke, 2006, pp. 89-120.

42. Bourke, 2011, p. 12 y nota 17.

43. Burton, 2015, p. 82.

44. Quintiliano, Instituciones oratorias XII 10, 9.

45. Lapatin, 2010, p. 142.

46. Dion Crisóstomo, Discursos XII 25. Sobre Dion de Prusa y la estatua del Zeus de Olimpia, ver Betz, 2004. 
Como ha apuntado Pollit, "ninguna imagen de culto posterior a la época de Fidias quedó libre de su huella". Su Atenea y sobre todo el Zeus "se convirtieron en modelos prototípicos para la representación de la divinidad". ${ }^{47}$

Para Dion de Prusa, aquellos que realizaban imágenes de los dioses eran una de las cuatro fuentes que enseñaban a los humanos acerca de los dioses, junto con la naturaleza, los poetas y mitólogos y los legisladores; incluso proporcionaba una lista de artistas griegos que representaban lo divino en diferentes formas. ${ }^{48}$ Para él, la imagen del Zeus de Olimpia es, de todas las estatuas en la tierra, la más hermosa y la más querida por los mismos dioses. ${ }^{49} \mathrm{Y}$ sin embargo, achaca a Fidias el haber creado una obra de arte demasiado perfecta, usando la técnica crisoelefantina, con forma humana y unos atributos específicos, que habrían eliminado la posibilidad de que cada uno pudiera usar su propia imaginación. En su discurso, Dion incluye la defensa de Fidias, poniendo en su boca la explicación: todos los humanos tienen un anhelo de los dioses, que puede ser satisfecho por una representación, y entonces lo divino se manifiesta en forma humana..$^{50}$ Intenta mostrar que el Zeus de Fidias encarna "todos los títulos por los que Zeus es conocido.". ${ }^{1}$ Como señor de los héroes y padre de dioses y hombres, la imagen del dios mismo parecía aproximarse al concepto de deidad universal. ${ }^{52}$

Ya Platón apuntaba que cuando los artistas intentan representar el mundo de las ideas en el plano material, yerran al confundir lo material con las ideas; con la excepción, sin embargo, de los grandes artistas que son capaces de expresar la idea latente a través de la piedra, el metal o la madera. ${ }^{53} \mathrm{El}$ impacto estético y emocional (pathos) producido por la contemplación de la imagen no se produce por la imagen en sí misma, sino por el propio dios. Sólo un gran artista, con una gran capacidad creativa, podría materializar este efecto, produciendo una imagen viva que se aproxima al dios original por asimilación (homoiosis)..$^{54}$ Por su parte, en el neoplatonismo, Plotino señala que Fidias no realizó el retrato de Zeus gracias a un modelo que pudiera ver con la ayuda de sus sentidos, sino que entendió cómo Zeus quisiera manifestarse si se hiciera visible. ${ }^{55}$

\footnotetext{
47. Pollit, 1987, p. 89.

48. Dion Crisóstomo, Discursos XII 44.

49. Dion Crisóstomo, Discursos XII 25.

50. Dion Crisóstomo, Discursos XII 60-61. Cf. Nasrallah, 2010, pp. 232-233.

51. Dion Crisóstomo, Discursos XII 75-78.

52. Harrison, 1996, p. 61.

53. Platón, República 10 (595a-608b).

54. Auffarth, 2010, p. 469.

55. Plotino, Enéadas V 8, 1, 38-40.
} 


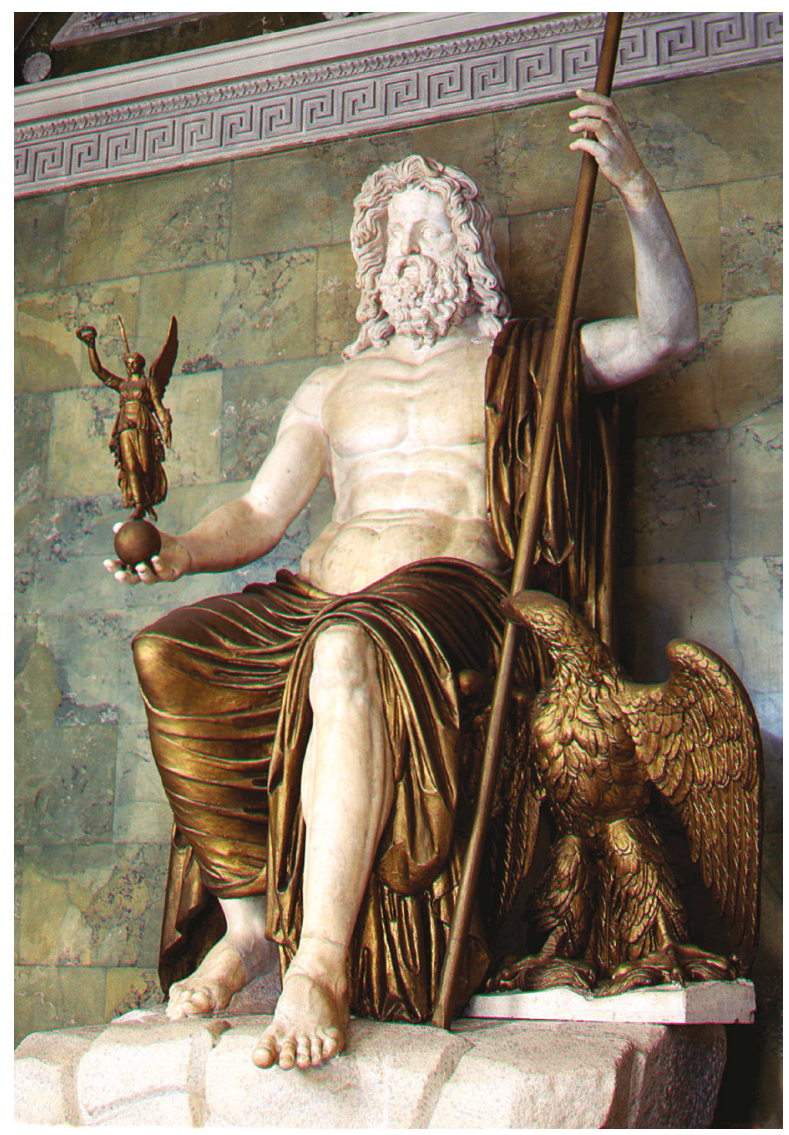

Fig. 3. Júpiter. Hall del Palacio de Invierno, Museo del Hermitage. San Petersburgo. Inv. No. A 362. Mármol del siglo I d.C. Partes doradas realizadas en yeso pintado en el siglo XIX. (Licencia de dominio público de Wikimedia Commons).

El Zeus de Olimpia de Fidias sirvió como modelo apropiado de imagen divina para el dios supremo del mundo griego - y después, en el mundo romano, tuvo una influencia decisiva en el Júpiter Capitolino - en el discurso teorético e intelectual, pero del mismo modo al marcar los criterios estéticos y religiosos. Dejando aparte el gran número de representaciones en monedas y gemas, la estatua fue objeto de copias o imitaciones en otras estatuas y estatuillas, pero como la mayoría de estatuas de mármol no han conservado sus extremidades y atributos, no podemos estar seguros de que se traten en realidad de copias, adaptaciones posteriores o un tipo genérico. ${ }^{56}$ Algunos ejemplos de imágenes de Zeus o de Júpiter en los que se percibe su influencia son famosos, incluso: el Zeus del Museo del Hermitage, el Júpiter Verospi de los

56. Lapatin, 2011, p. 90. 
Museos Vaticanos - en este caso, réplica del Júpiter Capitolino - o un bronce del s. II de la región de Haskovo, en Bulgaria.

Ya hemos comentado que la imagen del Zeus de Olimpia sirvió de modelo de imagen divina, no sólo a nivel teórico sino también en el sentido estético y religioso. El caso de Serapis demostraría cómo el modelo podría ser utilizado en este sentido: en la transformación del dios original egipcio, el buey Apis, con el propósito de exportarlo fuera de Egipto bajo la forma del nuevo Serapis, se adapta el modelo del Zeus de Fidias, el retrato de un hombre maduro, barbado y con el pelo largo, con un atributo diferenciador para hacerle reconocible, el modus sobre su cabeza ${ }^{57}$, y otra diferencia característica con el Zeus: donde éste aparecía con el torso desnudo y con un pliegue del himatión cayéndole por el hombro izquierdo, Serapis es representado con el quitón cubriendo su torso. El autor al que suele atribuirse una de las más importantes y quizá la primera representación de Serapis, Briaxis, en torno al 320-300 a.C., lo hizo de tamaño colosal, sedente en un trono, con un cetro en una mano, barba y la corona de cabellos enmarcando su rostro; además, se realizó con varias clases de metal, entre ellas oro y plata, y con piedras preciosas engastadas. ${ }^{58}$ Todo ello parece remitirnos al modelo del Zeus de Olimpia.

Pero la estatua del Zeus de Olimpia crea un arquetipo que llegará hasta nuestros días, no sólo como imagen divina, sino también como imagen imperial. ${ }^{59}$ Ya el emperador Calígula había intentado infructuosamente el traslado de la estatua a Roma, como nos cuenta Pausanias, para colocar su propia cabeza sobre ella. ${ }^{60}$ Evidentemente, ese arquetipo llegó a Roma como podemos constatar con el Júpiter Capitolino. Los emperadores romanos captan enseguida las posibilidades propagandísticas que encierra esta iconografía y copian su postura, su porte majestuoso, la inclusión de atributos de poder en las manos... todo para potenciar la imagen del poder imperial. Así, vemos numerosas representaciones escultóricas de emperadores romanos en las que queda patente que el modelo ejerció una poderosa influencia, instaurando una iconografía para la representación del dios supremo, Zeus-Júpiter, y posteriormente influyó en la representación de la figura del emperador divus. Será ahora la propia figura del empera-

57. Auffarth, 2010, p. 473.

58. Clemente de Alejandría, Protréptico IV 48. Cf. Pollitt, 1987, pp. 145-146.

59. Lapatin, 2010, p. 151.

60. Pausanias, Descripción de Grecia V 22, 3 y 57: “...ordenó que se trajeran de Grecia las estatuas de los dioses más admiradas por su culto o por su arte, entre ellas la del Júpiter [Zeus] de Olimpia, para, una vez descabezadas, ponerles la suya propia [..] En Olimpia, la estatua de Zeus que había ordenado desarmar y enviar a Roma, emitió de repente tan gran carcajada que los obreros dejaron caer sus herramientas y echaron a correr...”. 
dor la que aparecerá representada siguiendo este mismo estilo compositivo, quedando ya plenamente asumido este modelo iconográfico. ${ }^{61}$ Así, vemos numerosos ejemplos: desde Octavio Augusto, Tiberio y Claudio... hasta Constantino, con el coloso sedente acrolítico cuyos restos podemos ver hoy en los Museos Capitolinos. ${ }^{62}$

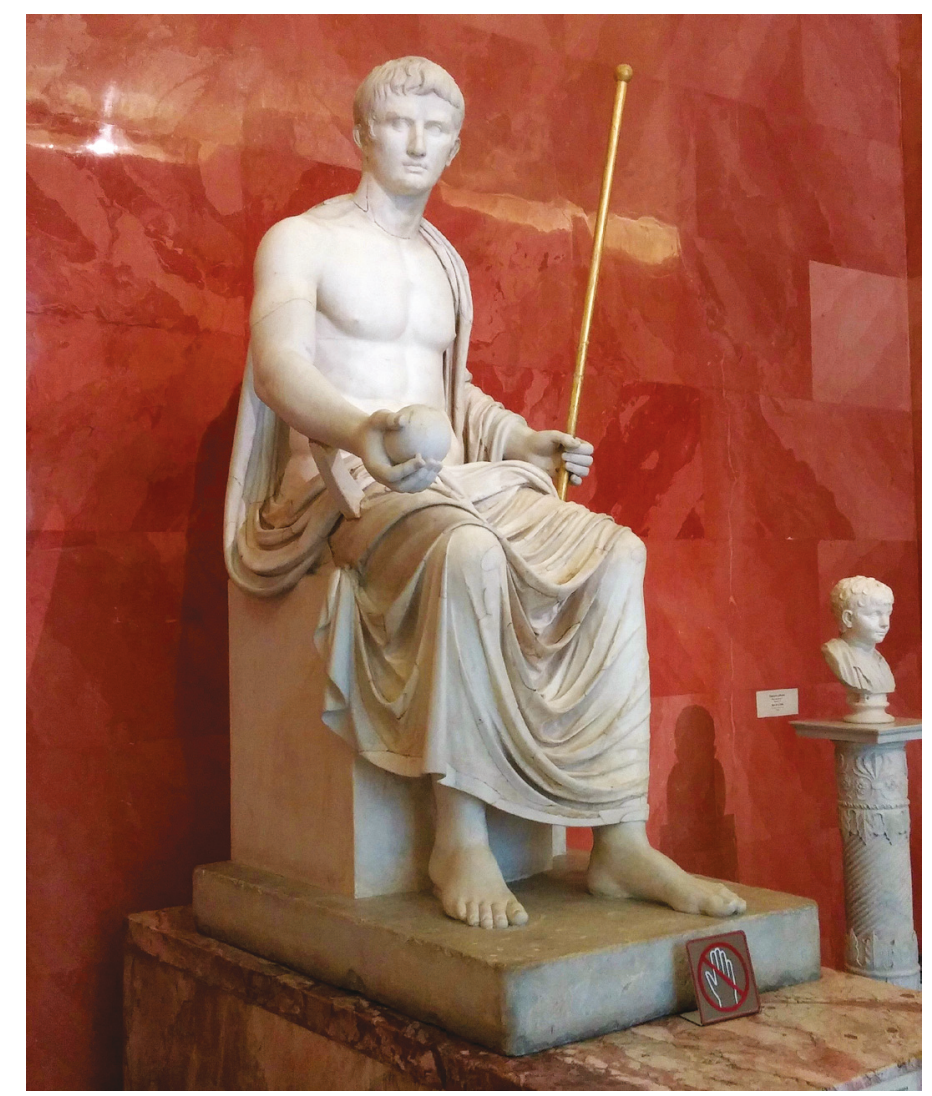

Fig. 4. Estatua de Octavio Augusto como Júpiter. Museo del Hermitage.

San Petersburgo. Inv. no A 399. Mármol de la primera mitad del siglo I d.C. (Licencia de dominio público de Wikimedia Commons).

61. Por supuesto, no fue la única influencia. Resulta muy probable que las estatuas de los primeros emperadores sirvieran, así mismo, de modelo para las de los siguientes.

62. Lapatin, 2011, p. 90: este autor afirma que seguramente el coloso de Constantino habría sido realizado en ese tamaño y con el tipo sedente para recordar la estatua de Zeus de Fidias. 
Precisamente desde la época de Constantino, al convertirse el Cristianismo en una religión pública, tuvo necesidad de tener una presencia monumental en el ámbito público, lo que le llevó a tomar parte del "lenguaje" común de la religión en el contexto greco-romano (como ocurrió en el caso de Serapis), pero con algunas diferencias específicas. Durante el periodo de adaptación, se puede observar una evolución: en un primer momento, hasta la época de Teodosio I, Cristo fue representado como un hombre joven, imberbe y con el típico corte de pelo del emperador, a la moda de los príncipes en la corte imperial, y después, sobre todo en la época de Teodosio II, la figura joven y apolínea de Cristo se sustituirá por una imagen majestuosa, solemne y revestida de poder y grandeza, con cabellos largos y con un rostro barbado "netamente influido por la espléndida estatua que talló Fidias para el Templo de Zeus en Olimpia", que va a ser conocido como el Pantocrátor. ${ }^{63}$ Posteriormente, se notarán sutiles variaciones, como una expresión de mayor bondad en el rostro, los labios son más gruesos y los ojos más afables, ${ }^{64} \mathrm{y}$ se introduce la aureola o nimbo que denota la divinidad del personaje. ${ }^{65}$

En cuanto a sus vestiduras, sin embargo, en esas imágenes Cristo es representado con la túnica cubriéndole el torso y el cuerpo entero y, en ocasiones, con el manto por encima. El dorado de sus vestiduras, además de diferenciarle de los ciudadanos, que tradicionalmente vestían sobre todo de blanco, debería ser entendido como atributo de la propia divinidad en conjunción con la aureola o nimbo ${ }^{66}$ Los dioses representados en las grandes imágenes de culto de la Antigüedad solían aparecer con ropajes de oro. Así pues, cuando Cristo aparece representado con la aureola y las vestimentas doradas, no es que se pretenda caracterizarle como emperador, sino subrayar su divinidad. El primer Concilio de Nicea (325) no proclamó a Cristo emperador, sino "Dios de Dios, luz de luz, Dios verdadero de Dios verdadero, engendrado, no creado, de la misma naturaleza que el Padre". ${ }^{67}$

Al igual que sucede con las vestiduras, como ya veíamos anteriormente, el trono en el que se sienta Cristo es un atributo tomado directamente del Zeus de

63. Paynes, 1974, p. 215. Ver también Auffart, 2010, p. 466, pp. 473-474.

64. Paynes, 1974, p. 215.

65. Errazúriz y Balbontín, 1999, p. 120.

66. Mathews, 1993, p. 101. Este autor critica las identificaciones de la aureola, halo o nimbo de Cristo como un atributo imperial. Es cierto que tuvo cierto uso imperial y en cualquier caso habría tenido un uso previo como atributo de los dioses, que es por lo que los emperadores habrían deseado apropiárselo. Es el caso conocido del Disco de Teodosio, en el que aparece el emperador con el nimbus (Real Academia de la Historia, Madrid). Ver Almagro Gorbea et al., 2000.

67. Ibidem. 
Fidias y no de las representaciones de emperadores romanos del Alto Imperio, en las cuales, aunque sí que puede observarse una gran dosis de apropiación de los atributos y de la postura del Zeus - o del Júpiter Capitolino -, no se copia el trono, sino que es sustituido por la silla curul. El trono (thronos, en griego; solium, en latín) básicamente era una silla con patas rectas y respaldo, con o sin apoyabrazos. El arte antiguo muestra a Dionisos, Plutón, Afrodita y Hera entronizados en algunas ocasiones, pero sobre todo, el trono es atributo característico del padre de los dioses, Zeus-Júpiter. Cristo nunca aparece sentado en una sella curulis, dado que no es representado como emperador, sino como divinidad. El más antiguo mosaico absidial cristiano de Roma que muestra a Cristo entronizado es el de la basílica de Santa Prudenciana (c. 410-417): el enorme trono presenta un respaldo alto, no tiene apoyabrazos y sus anchas patas rectas están recubiertas con incrustaciones de perlas y gemas. Tiene un cojín carmesí de tonos anaranjados (no el púrpura imperial), y va acompañado de un escabel a juego, todo lo cual nos recuerda, una vez más, al modelo del Zeus de Fidias. Como señalaba Mathews, "es precisamente aquí donde se estaba luchando la guerra de las imágenes con más intensidad. Usurpando los atributos de los antiguos dioses, Cristo los estaba suplantando de manera efectiva". ${ }^{68} \mathrm{Al}$ intentar darle a Cristo el mismo estatus que a Dios Padre, se toman prestados de Zeus-Júpiter su trono, su rostro, su postura y sus vestiduras doradas. En este mismo sentido, si retomamos el discurso de Dion de Prusa, encontramos una descripción del Zeus que bien podríamos encontrar siglos después en cualquier referencia al Pantocrátor o al Dios Padre cristiano:

“...apacible y majestuoso en postura impasible, como dador de vida, de sustento y de toda clase de bienes, como padre, salvador y protector común de los hombres (...) padre y rey, ciudadano, congénere, amigable y compañero, y además, suplicante, refugiado, hospitalario, poseedor, cosechero y muchos miles de epítetos distintos, todos ellos buenos. Rey se le llama por su poder y su fuerza, padre por sus cuidados y afabilidad...”. ${ }^{69}$

68. Ibidem, p. 108.

69. Dion Crisóstomo, Discursos XII, 75-76. 


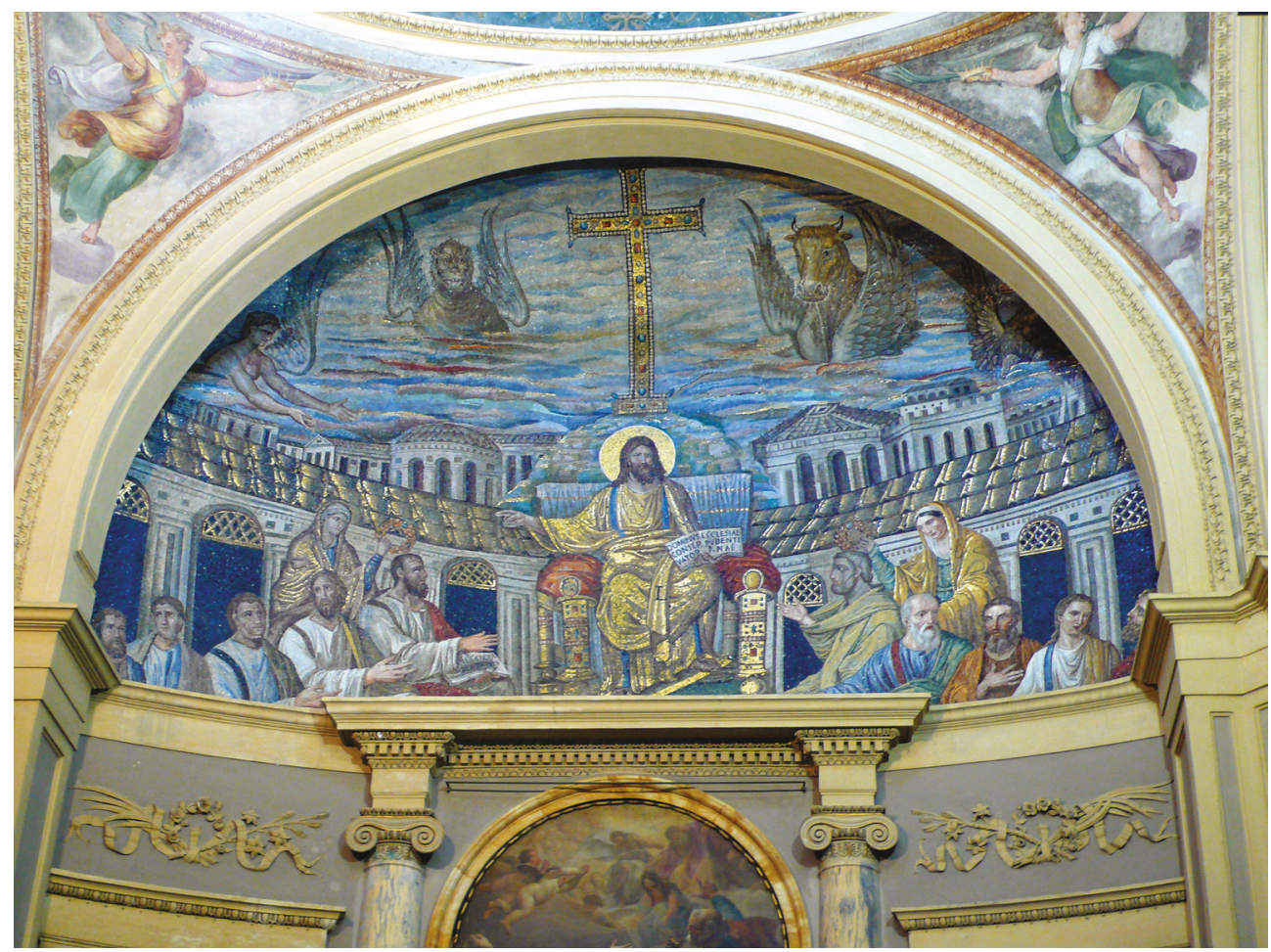

Fig. 5. Mosaico absidial de la basilica de Santa Prudenciana, Roma. (c. 400) (Licencia de dominio público de Wikimedia Commons).

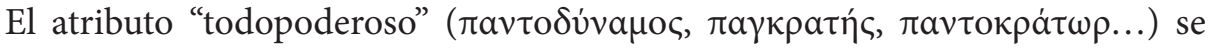
había aplicado a Zeus en obras trágicas de Esquilo o Sófocles, y se había aplicado también a otros dioses. ${ }^{70}$ Siguiendo esa corriente de apropiación mencionada, el Cristianismo lo atribuyó a Dios Padre o a Cristo en majestad. Salvando el ejemplo ya comentado del mosaico de la basílica de Santa Prudenciana en Roma, será en Constantinopla donde encontraremos el inicio de lo que podemos denominar una iconografía típica de pantocrátor que aparecerá en los mosaicos bizantinos, evolucionará hasta los iconos ortodoxos griegos o rusos, hasta la iluminación de evangeliarios en

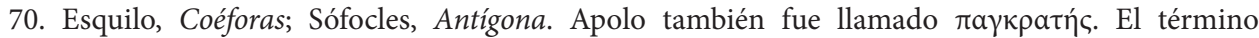
$\pi \alpha \nu \tau$ к $\rho \alpha \dot{\tau} \omega \rho \rho$, concretamente, aparece constatado por primera vez en la literatura pagana en un himno

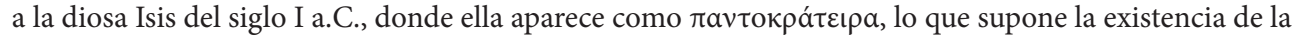
forma masculina (Papiro de Oxirrinco 1380, 1, 20). 

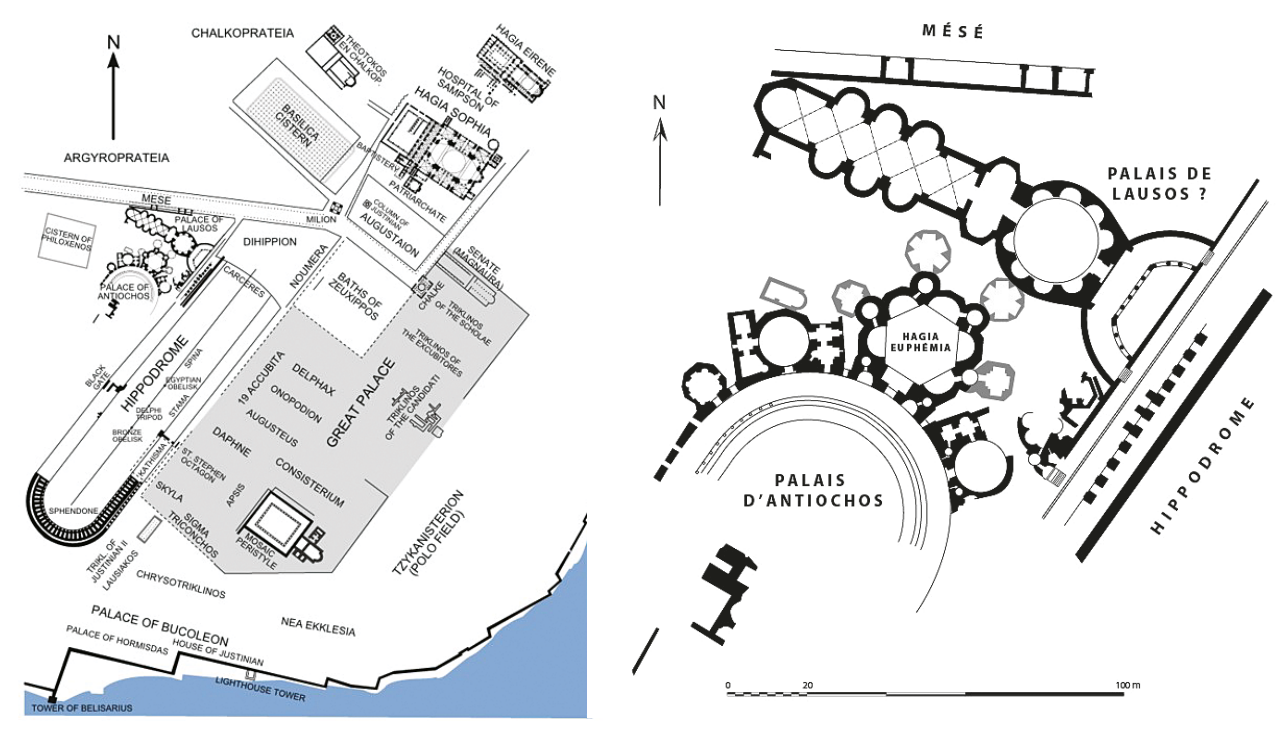

Fig. 6-7. Centro monumental de Constantinopla con el Gran Palacio, el Hipódromo y Santa Sofía, y El Palacio de Lausos y el Palacio de Antíoco, junto al Hipódromo en Constantinopla. Mapas adaptados a partir de Müller-

Wiener, 1977 (Licencias de dominio público de Wikimedia Commons).

miniaturas carolingias y románicas, y pasará a la escultura en las portadas románicas y góticas. Cuando se represente el Juicio Final, presidido por el pantocrátor, se destaca en Cristo especialmente su carácter de juez, al igual que el Zeus de Fidias inauguró una forma de representación de este dios como árbitro, con un significado especial en Olimpia, como ya mencionamos anteriormente. ${ }^{71}$

Cabría preguntarse cómo habría llegado la influencia de la estatua de Zeus de forma tan clara al centro del poder imperial en Constantinopla, y para ello deberíamos analizar su destino final. Algunos estudiosos han puesto en duda el traslado de la estatua a Constantinopla por dificultades logísticas, ${ }^{72}$ pero debemos tener en cuenta que la estatua era desmontable y, por otro lado, en ese momento los ingenieros y el propio transporte romano estaban acostumbrados a este tipo de empresas, sobre todo después del traslado de numerosos obeliscos egipcios a Roma. En las excavaciones arqueoló-

71. Barringer, 2015, p. 14.

72. Ver, por ejemplo, Green, 1978, p. 30: "it is hard to see how such a statue could be transported". 


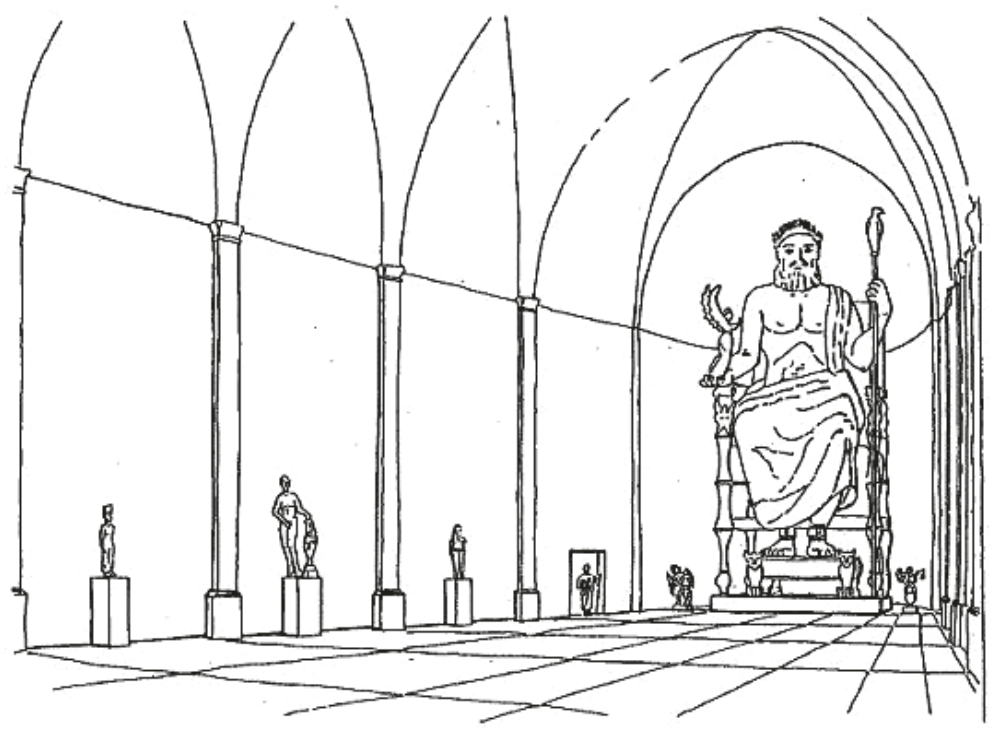

Fig. 8. Propuesta museográfica de Mango, en Mango, Vickers y Francis, 1992, p. 94.

gicas en Olimpia no se ha encontrado ningún resto de la estatua de Zeus, cuando, por otro lado, encontramos referencias literarias a la misma que la sitúan en el palacio de Lauso, en la ciudad del Bósforo. La primera aparece en Synopsis Historion de Cedreno, del s. XI, cuando se refiere a una colección de estatuas de Lauso, un eunuco de la corte de Teodosio II convertido en alto funcionario, cercano a las élites imperiales, en torno al 420. Según Cedreno, entre las obras estaban: "La Afrodita de Cnido de mármol blanco, desnuda, que cubría sus virtudes con las manos, obra de Praxíteles. También (...) el Zeus elefantino de Fidias, que Pericles dedicó en el templo de Olimpia." ${ }^{73}$ Esta es la referencia más directa que tenemos de su ubicación en Constantinopla. Pero, sin hacer

73. Jorge Cedreno, Synopsis Historion, I, Bonn, ed. I. Bekker, 1838, 564; ver Mango, Vickers y Francis, 1992, pp. 89-98. 
alusión explícita a la estatua de Zeus, también se puede intuir su presencia en esta galería de arte de Lauso, en el Epitome Historion de Juan Zonaras, del s. XII. ${ }^{74}$

Se identifican con el palacio de Lauso los restos de un importante complejo encontrados muy cerca del Hipódromo; se trata de una gran basílica de recepción con un gran ábside y otros seis flanqueándolo, todo precedido de una gran rotonda que se abre a la calle con un gran peristilo. Como sugiere Mango, el edificio parece construido ex profeso para la exposición de todas las obras, habiéndose reservado para el gran Zeus el ábside frontal. ${ }^{75}$

En cualquier caso, parece que hay suficientes evidencias como para poder pensar que el Zeus de Fidias estaba, de este modo, presente en el corazón de la capital cristiana. ${ }^{76}$ De aceptarse esta hipótesis, Lauso habría coleccionado en su palacio muchas obras de arte cuyo uso para el culto ya no estaba permitido. Llevadas a Constantinopla, habrían servido como obras maestras del arte clásico. Entre éstas, de forma prominente, se habría encontrado la estatua de Zeus de Olimpia realizada por Fidias, que además destacaba por ser una de las Siete Maravillas del mundo antiguo.

\section{El Coloso de Rodas}

La imagen visual de una estatua gigante con las piernas abiertas a la entrada del puerto es universalmente conocida, y en el acto nos hace pensar en el término "colosal"; sin embargo, el Coloso de Rodas es, probablemente, la más desconocida de las Siete Maravillas de la Antigüedad junto a los Jardines Colgantes de Babilonia, y la que ha dado lugar a más interpretaciones. No se ha descubierto nunca vestigio alguno del Coloso, y para encontrar noticias sobre él hay que buscar en fuentes muchas veces difíciles de interpretar, pero su legado es indiscutible, y la tradicional imagen que conservamos en nuestro imaginario colectivo, creada en el Renacimiento, es fuente de múltiples influencias en la Historia del Arte. En lo que se refiere a su influencia en la iconografía cristiana, veremos que se trata de un caso netamente diferente del que acabamos de analizar en relación con el Zeus de Olimpia, sobre todo porque dicha

74. Juan Zonaras, Epitomae historiarum, Bonn, ed. Th. Büttner-Wobst, 1897, p. 131; ver Bassett, 2000, p. 7.

75. Mango, Vickers y Francis, 1992, pp. 93-94.

76. Breckenridge, 1959, pp. 57-59. La estatua habría estado en Constantinopla durante un periodo de tiempo de entre cincuenta a setenta años, hasta su presunta destrucción en el incendio del año 475. Cf. Stevenson 2007; Stevenson 2011: aun soportando esta misma idea después de un profundo análisis de la problemática del transporte y de su posible presencia en Constantinopla, Stevenson recuerda que la evidencia es débil y que cualquier afirmación al respecto debería tomarse con cautela. 
influencia apenas se manifestó en la Antigüedad y sólo en época muy reciente se ha materializado en imágenes cristianas por todo el orbe.

Pero, ¿cuál era el aspecto del Coloso? Sólo podemos elucubrar a partir de datos dispersos, y como ya hemos señalado, muchas veces difíciles de descifrar; su temprana destrucción debido al terremoto de 226 a.C. nos ha dejado sin apenas vestigios de su aspecto real. ${ }^{77}$ En época imperial aún quedaban restos visibles y reconocibles, pero casi con toda seguridad éstos se perdieron hacia finales del s. IV o en la invasión árabe de la isla en plena expansión islámica. Sobre todo, tenemos noticias acerca de su tamaño majestuoso, como indica Estrabón:

"La mejor [de las ofrendas] es el coloso de Helios, del que el yambógrafo afirma que: De siete veces diez codos lo hizo Cares de Lindo, pero ahora yace por tierra derribado por un terremoto y partido por las rodillas. No lo volvieron a levantar por un oráculo. Éste es la más importante de las ofrendas y se le considera una de las Siete Maravillas". ${ }^{78}$

La descripción más pormenorizada la encontramos en Filón de Bizancio, ${ }^{79}$ que habla con mucha precisión del entorno donde se realizó la escultura y de la propia técnica de construcción, y nos da quizás las pistas más fiables de su aspecto. Este texto, y otros que hablan de la estatua, ${ }^{80}$ coinciden en que se trata de una estatua de bronce con una altura de unos 70 codos - 32 a 35 metros - y que era una ofrenda votiva al dios Helios. Resulta increíble que no tengamos ni una sola imagen del Coloso, aun cuando encontramos monedas de Rodas que posiblemente representan el rostro del dios Helios que tenía la estatua ${ }^{81}$. El Coloso sigue apareciendo mencionado como una maravilla del mundo en las listas de autores cristianos como Gregorio de Tours o Beda el Venerable, o en menciones de otros, como Eustacio de Tesalónica (s. XII) o Jorge Cedreno (s. XIII) - mientras que dejan de hacerlo con el Zeus, que no vuelve a aparecer hasta el Renacimiento -, pero pese a su fama, también sigue siendo una maravilla bastante desconocida, más allá de su tamaño colosal. ${ }^{82}$ Esta falta de información ha condicionado la imagen que nos ha llegado desde los grabados del Rena-

77. Respecto a las fuentes clásicas que hablan del terremoto y la caída del Coloso, ver: Polibio, V 88, 1, y Scholia a Platón, Philebos, 15 c.; Plinio, Historia Natural XXXIV 41. Ver también Holleaux, 1923; Guidoboni et al., 1994, 140; Rieger, 2004.

78. Estrabón, Geografía XIV 2, 5, C 652.

79. Filón de Bizancio, De septem orbis spectaculis 4.

80. Estrabón, Sexto Empírico, Plinio, Polibio.

81. Tetradracma de plata del Museo Británico: véase Maryon, 1956, p. 43; moneda de Rodas con la imagen de Helios, del Museo Numismático de Atenas. Para saber más: Ashton, 1988, pp. 75-90.

82. Brodersen, 2010, pp. 121-144. 


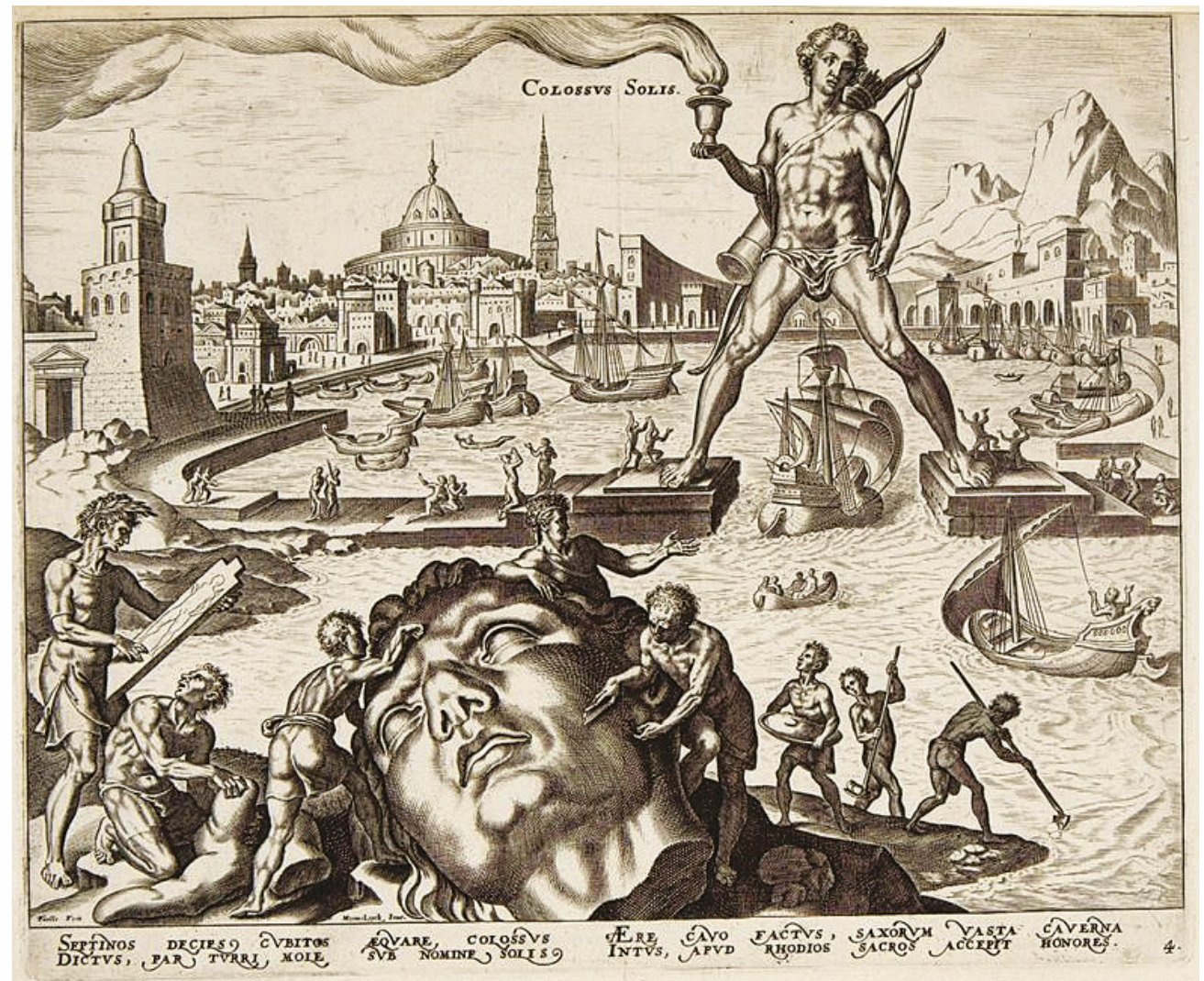

Fig. 9. Coloso de Rodas, grabado de Maarten van Heemskerck, serie sobre las Siete Maravillas del Mundo, 1572. (Licencia de dominio público de Wikimedia Commons).

cimiento, una estatua desnuda con las piernas abiertas sobre la bocana del puerto, a veces con una antorcha encendida en la mano alzada, a modo de faro. ${ }^{83}$ Esta visión es

83. Nicolás de Martoni, un peregrino italiano, en su viaje a Jerusalén se detiene en Rodas, en torno al 1394-1395, y nos deja esta referencia: "Al final del muelle hay una iglesia con el nombre de San Nicolás, y me han dicho y confirmado que en tiempos antiguos hubo una gran maravilla, un gran ídolo, tan admirablemente formado que se dice que tenían un pie en la punta de dicho muelle donde está la iglesia de San Nicolás, y el otro en la punta del otro muelle, donde están los molinos”. Ver Le Grand, 1984. Pero, como sugiere Ursula Vedder, este peregrino no es el que se inventa la historia, sino que estaría transmitiendo interpretaciones erróneas de antiguas fuentes. Ver Vedder, 2006. De todas formas, no podemos 
el punto de partida perfecto para la iconografía propia del Coloso que se dará a partir del Renacimiento, una imagen mucho más plástica y sugestiva que ha dado lugar a múltiples influencias artísticas.

Hoy podemos asegurar que esta postura resultaría del todo inviable en el momento en que se construyó, incluso si tomamos en cuenta que se llenó el interior de la estatua de piedras y travesaños, como señala Filón de Bizancio, y también Plinio. ${ }^{84}$ Obviamente, esta imagen resulta mucho más atractiva y romántica, pero la realidad se acercaría más a una escultura recta, con los pies juntos, al estilo de los kuroi antiguos, pero con la técnica más avanzada heredada de Lisipo y perfeccionada por Cares para la ocasión. Filón también nos da otra pista sobre su aspecto al relatar que la estatua se sentaba sobre una gran basa de mármol, en singular, por lo que los pies no podían estar muy separados; si la estatua hubiera estado con las piernas abiertas sobre el puerto, se hubieran necesitado dos basas, y con la precisión que habla Filón, habría sido un dato que no hubiera omitido.

¿A qué hace referencia exactamente el término kolossos? Para Kai Brodersen, ${ }^{85}$ en el dialecto dorio de Rodas esta palabra significaba sencillamente "estatua", y dado el tamaño del Coloso de Rodas, la antigua palabra kolossos adquirió el significado de "estatua gigante", perdurando en nuestro vocabulario con los términos "coloso" y "colosal". Manfredi ${ }^{86}$ indica que es un vocablo propio del mundo minorasiático que hace referencia a ídolos anicónicos y posteriormente se empleó para denominar a las estatuillas votivas que se dejaban en los santuarios, para acabar, por extensión, aplicándose a cualquier estatua. Existen diversos estudios, sobre todo filológicos, acerca del término kolossos ${ }^{87}$ y también Ursula Vedder ${ }^{88}$ habla de "idolum" como los antiguos kolossos o estatuillas mágicas. En cualquier caso, lo que se puede concluir de forma clara es que el impacto que tuvo esta estatua le dio al término para referirse a ella un nuevo significado que ha permanecido hasta nuestros días. Fue tal su importancia que, por extensión, cualquier estatua de gran tamaño pasó a

asegurar completamente dónde se erigió, ni su aspecto, ni la técnica empleada para su construcción, sólo tenemos teorías que no hacen sino demostrar la enorme fascinación que ha suscitado a lo largo de los tiempos esta maravilla de la Antigüedad.

84. Plinio, Historia Natural XXXIV 18, 41: "en su interior pueden verse piedras de enormes dimensiones que Cares había utilizado para dar estabilidad a la estatua mientras la construía”.

85. Brodersen, 2010, pp. 111-114.

86. Manfredi, 2017, pp. 83-84.

87. Sobre todo, Benveniste, 1932, p. 118; Dickie, 1996, pp. 237-257.

88. Vedder, 2006. 
denominarse "coloso", y hoy podemos hablar de su gran influencia en la "estatuaria colosal", partiendo del propio término.

El propio maestro de Cares, Lisipo, había realizado en Tarento un Zeus de bronce de 17 metros y un Heracles de 6 metros ubicado en la acrópolis. En ambas estatuas, Lisipo idea soluciones para dotar de estabilidad a sus obras, como un pedestal basculante que no ofrece resistencia al viento, o situar un pilar cerca para atenuar la fuerza del mismo. ${ }^{89}$ El Heracles fue llevado al Capitolio de Roma y posteriormente acabó adornando Constantinopla, así que la estatuaria colosal era bien conocida.

Ya que las fuentes no nos pueden dar una descripción detallada de esta maravilla, resulta interesante ver cómo se ha construido la imagen que tenemos del Coloso e intentar entender los procesos de identificación de lo que podemos llamar "réplicas" de la estatua, o más bien, reinterpretaciones de esa imagen más plástica y visual que parte del Renacimiento.

En 1554 André Thevet publica Sobre la Cosmografía del Levante, fruto de su viaje de exploración por Asia, Grecia, Palestina y Egipto; aquí encontramos una figura del Coloso que nombra como maravilla del mundo, y aparece con las piernas abiertas y los barcos pasando bajo ellas, una espada y una pica en las manos y un espejo colgado del pecho. ${ }^{90}$ Esta imagen será recuperada por Orazio Tigrini en Li sette miracoli del' mondo, obra grabada por Franz van Aelst entre 1574 y 1578, con la diferencia de las piernas juntas sobre una basa. ${ }^{91}$

Como vemos, la figura del Coloso con las piernas abiertas sobre la bocana del puerto aparece a comienzos del s. XVI, pero es con Maerten van Heemskerck con quien encontramos una pintura que presenta una estatua sobre la entrada a un puerto en "Paisaje con el rapto de Helena" realizada en Roma en 1535. Para la figura del Coloso, el artista utiliza sus propios bocetos del Hércules Capitolino junto a fragmentos de la estatua colosal de Constantino. Estos trabajos sirven de preparación para lo que será la imagen del Coloso que más ha influenciado y que quedó como modelo de referencia, junto a los demás grabados que realizó sobre las Siete Maravillas en 1572, y que se constituyeron en lista "oficial" de las Siete Maravillas de la Antigüedad, siendo dichas imágenes el referente obligado a partir de ese momento.

89. Plinio, Historia Natural XXXIV 37 y 40.

90. Thevet, 1554, p. 105.

91. Tigrini, 1574-1578. 
Esta imagen del Coloso será copiada y reinterpretada en múltiples grabados a partir de este momento, como el de Antonio Tempesta. ${ }^{92}$ Posteriormente, en las series de grabados de las Siete Maravillas del mundo de Crispin de Passe de 1614, basados en Maarten de Vos y en la obra de 1660 de Jacques Picart vemos que ya ha quedado marcado un arquetipo bien definido. ${ }^{93}$ Este modelo de representación continuará prácticamente igual, salvo que se centrará en la imagen del Coloso, perdiendo protagonismo los personajes que aparecían en primer término, según se va pasando del Humanismo renacentista al Barroco y Neoclásico después. ${ }^{94}$

Johann Bernhard Fischer von Erlach, en su obra "Plan de Arquitectura Histórica y Civil", realiza uno de los primeros estudios comparativos de la arquitectura a nivel global e incluye grabados entre los que nos interesa el del Coloso de Rodas. En él no sólo recoge la tradición representativa que estamos viendo sino que va más allá en su estudio, pues muestra la estatua junto a unas monedas rodias para argumentar su diseño. ${ }^{95}$

En el siglo XIX, las distintas interpretaciones de la figura del Coloso de Rodas mantienen prácticamente las mismas características y nos presentan precedentes directos para el modelo de la Estatua de la Libertad, aun cuando aparezcan con las piernas separadas, pues se impone la idea de la antorcha encendida. Otra imagen, sin embargo, sugiere una postura más plausible, con interesantes conexiones, como sugiere Nathan Badoud cuando habla de la influencia de una estatuilla de Sol Invictus en la reconstrucción de Louis Bernier, ${ }^{96}$ y que nos recuerda a la reconstrucción que hace Höpfner. ${ }^{97}$

En el Coloso de Rodas, sobre todo resalta el sentido propagandístico del tamaño de la estatua en sí mismo; las estatuas monumentales eran muy comunes para establecer con el pueblo una relación política, propagandística y religiosa, además de para generar prestigio e incluso impulsar la economía, ya desde el Imperio Nuevo egipcio. No debemos olvidar, además, que es una representación de Helios, y de ahí su influencia inmediata en el arte romano, y aquí no hay duda de la relación

92. Septem orbis miracula [...] in aeneas tabulas ab Antonio Tempesta Florentino relata, a Iusto Rychio Gaudene versibus celebrata, Roma, 1608.

93. Crispin de Passe: El Coloso de Rodas, 1614. Cr. van de Passe: Admiranda et prodigiosa antiquitatis opera, quae septem orbis miracula vulgo vocantur, Utrecht, 1614. Jacques Picart: El Coloso de Rodas: Cares de Lindo presenta el Coloso al rey, 1660.

94. Kircher, 1679: El Coloso de Rodas; Mallet, 1683, p. 152, fig. 127.

95. Von Erlach, 1721.

96. Reconstrucción de Louis Bernier (grabado de Sidney Barclay) para Augé, 1878, p. 17, citado por Badoud, 2012, p. 30. Estatuilla de Sol Invictus descubierta en Chalon-sur-Saone y conservada en el Gabinete de las Medallas de la Biblioteca Nacional de Francia, Bronce 114.

97. Höpfner, 2003. 
directa con el Coloso de Nerón, estatua de bronce diseñada por el arquitecto griego Zenodorus entre los años 64-68 d.C. y originalmente erigida para el vestíbulo de la Domus Aurea. ${ }^{98}$ Según Plinio, medía 30,3 metros de altura y representaba al emperador desnudo como Sol-Helios; tras la muerte de Nerón, Vespasiano la renombró Colossus Solis, cambiando la cabeza y los atributos. ${ }^{99}$ Adriano ordenó mover la estatua desde la Domus Aurea hasta el noroeste del Anfiteatro Flavio, para hacer sitio al Templo de Venus y Roma, lo que parece corroborar el dato de su gran tamaño; debido a ello, el Anfiteatro Flavio pasó a conocerse como Colosseum. Con Nerón se materializa, precisamente, esta idea del poder imperial-divino, siendo ahora la propia figura del emperador la que aparecerá representada como dios Helios. Y este modelo colosal - que también tiene herencia del Zeus y de las otras influencias que ya hemos mencionado en la primera parte de este artículo -, lo retomará casi tres siglos más tarde el emperador Constantino para realizar su gran estatua sedente de tipo acrolítico ${ }^{100}$ que habría de ocupar la cabecera oeste de la basílica de Majencio, en el Foro Romano. Tras la victoria de Constantino sobre Majencio en la batalla de Puente Milvio, Constantino amplió la basílica y añadió un ábside donde situaría la estatua. ${ }^{101}$ Tomando en consideración los restos que han llegado a nuestros días, podemos hablar de una estatua de unos 12 metros de alto, ya que la cabeza mide aproximadamente dos metros y medio y cada pie, más de dos metros.

Aunque existen diversos ejemplos de estatuaria colosal de otros emperadores romanos, para el caso que estamos estudiando en relación con el Cristianismo resulta especialmente significativo el conocido como "Coloso de Barletta", de más de cinco metros de altura y la única estatua colosal completa de bronce de un emperador de la Antigüedad Tardía, aún objeto de estudio para intentar conseguir una identificación entre las muchas posibilidades presentadas por los estudiosos. ${ }^{102} \mathrm{Su}$ pose y su tamaño colosal nos conducen a través del tiempo, junto con el propio modelo del Coloso de Rodas, hasta la estatua que, heredera hoy en día de aquella maravilla del mundo antiguo, se nos presenta como epítome de la estatuaria colosal contemporánea: la Libertad iluminando el mundo, más conocida como la Estatua de la Libertad, en Nueva York.

98. Albertson, 2001; Zgoll, 2016.

99. Plinio, Historia Natural XXXIV 45.

100. Estatua con torso de madera recubierto de metal y cabeza y extremidades de mármol. El estudio fundamental es el de Fittschen y Zanker, 1985, pp. 147-152, nº 122. Más recientes, Parisi Presicce, 2005 (especialmente, p. 154, nota 25) y Safran, 2006.

101. Ver, por ejemplo, Holloway, 2004; Lenski, 2012.

102. Kiilerich, 2015. También se podría mencionar la estatua colosal de bronce de Constantino en los Museos Capitolinos de Roma, de la cual sólo se conservan la cabeza y la mano izquierda. 
Frédéric Auguste Bartholdi ya había realizado un proyecto anterior - en 1870 -, que no se llegó a llevar a cabo, para una estatua destinada a marcar la entrada al canal de Suez: "Egipto iluminando Asia", un faro monumental con forma de mujer que si bien no llegó a ver la luz, sirvió como inmediato precedente para la Estatua de la Libertad. ${ }^{103}$ De nuevo, la situación en un paisaje portuario, su función de faro, la corona radiada en la cabeza, etc., retrotraen a la iconografía tradicional del Coloso de Rodas.

La inspiración en el Coloso resulta patente en múltiples aspectos: el tamaño, la ubicación, la postura - que también recuerda al Coloso de Barletta -, la corona radiada de Helios, el cuestionado faro o antorcha en la mano, y su simbología. El Coloso de Rodas sirvió a los rodios no sólo para conmemorar su victoria frente al asedio de Demetrio Poliorcetes en 305-304 a.C., sino también para demostrar al mundo su independencia y poder; de igual manera, la Estatua de la Libertad se concibió para conmemorar el centenario de la Declaración de Independencia de los Estados Unidos, inaugurándose en 1886, y se convirtió en un símbolo de este país y de la libertad en general frente a la opresión. En el propio pedestal de la Estatua de la Libertad se puede encontrar un poema titulado "El nuevo Coloso", ${ }^{104}$ y resultó una de las 21 finalistas en la votación de las "nuevas maravillas del mundo" que tuvo lugar el 7 de julio de 2007.

Podemos afirmar, sin miedo a equivocarnos, que la Estatua de la Libertad es el "nuevo Coloso" de nuestros días, y así ha contribuido a la recreación del arquetipo que proviene de la Antigüedad. A partir de este momento, la escultura contemporánea colosal va a presentar siempre, en mayor o menor medida, la influencia de esta iconografía heredada del Coloso de Rodas. ${ }^{105}$

Por consiguiente, es a partir de ese momento cuando vamos a poder detectar la influencia del Coloso de Rodas en la estatuaria colosal cristiana utilizada para las representaciones de Jesucristo o de la Virgen María que podemos encontrar en diferentes partes del mundo. Eso sí, donde el Coloso de Helios aparecía desnudo o casi desnudo, las imágenes cristianas - como también la Estatua de la Libertad - aparecen completamente vestidas en la mayoría de los casos.

Estas esculturas monumentales recuperan muchas de las características típicas del Coloso, no sólo el tamaño colosal, sino su ubicación, la mayoría de las veces en puertos o frente al mar, y el sentido de acción de gracias y veneración a un dios. Entre todos los ejemplos - y hay muchos - destaca por encima de todos ellos el Cristo Re-

103. Provoyeur, 1986, p. 75.

104. Soneto de Emma Lazarus en una placa de bronce añadida en 1903: "Not like the brazen giant of Greek fame, with conquering limbs astride from land to land...”.

105. Provoyeur, 1986. 


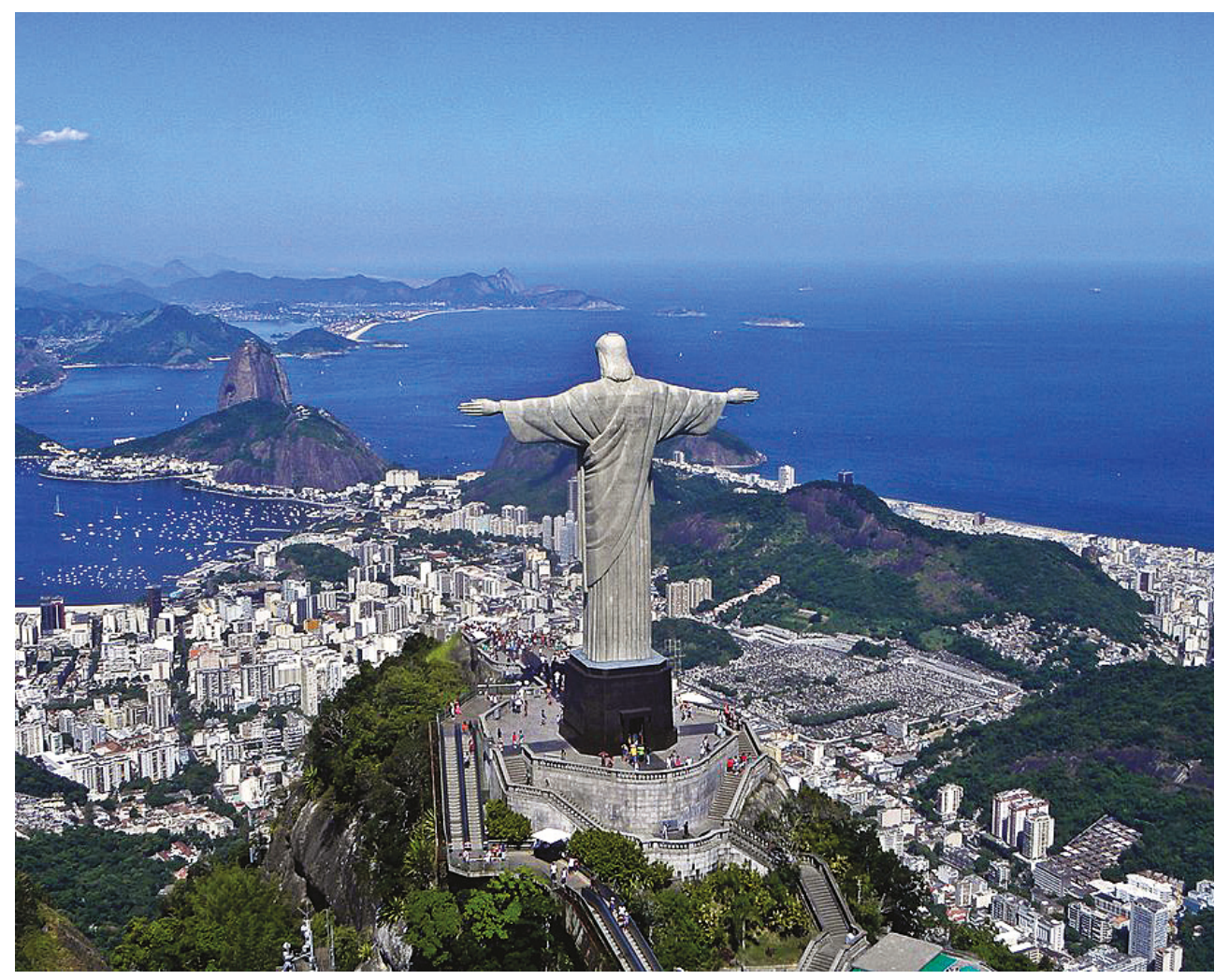

Fig. 10. Cristo Redentor o Cristo del Corcovado, Río de Janeiro, 1931. (Licencia de dominio público de Wikimedia Commons).

dentor o Cristo de Corcovado, en Río de Janeiro, una enorme estatua de 30,1 metros con un pedestal de 8 metros, situada a 710 metros sobre el nivel del mar, en la cima del cerro del Corcovado y frente a la bahía de Guanabara. Inaugurada en 1931, hoy forma parte de las nuevas Siete Maravillas del mundo moderno - no oficiales, dado que no están avaladas por la UNESCO -, y ha marcado la iconografía propia de estas esculturas, con los brazos abiertos en actitud de abrazo y redención.

Esta imagen de Cristo protector se concibe también como "faro" o "luz del mundo", volviendo a la herencia del Coloso; de hecho, una interpretación de la inscripción votiva del Coloso de Rodas es lo que ha dado lugar a la idea de faro o estatua con una antorcha en la mano: 
"En este lugar para ti hasta el Olimpo alzaron el coloso el de Rodas habitada por dorios, Helios, de bronce cuando tras calmar la ola de Enio coronaron su patria con los despojos de los enemigos. Y no sólo sobre el mar lo hicieron brillar, sino también en la tierra, precioso resplandor de libertad no subyugada. Pues éstos, crecidos del linaje de Hércules, tienen sus dominios patrios en el mar y en la tierra”. ${ }^{106}$

Estas palabras nos hacen entender mejor las representaciones del Coloso como faro, y el legado presente en la Estatua de la Libertad. Más allá de la interpretación literal en este pasaje sobre el Coloso como luz o linterna, la imagen poética del resplandor entronca con el sentido religioso y concede una influencia más en estos Cristos y Vírgenes monumentales, de los que hay muchos ejemplos, sobre todo en América Latina. Sin entrar a comentarlos en detalle, sirvan también de ejemplo los Cristos de la Habana, el Cristo del Pacífico en Perú, el Cristo de la Misericordia en Nicaragua, el Cristo de la Concordia en Cochabamba (Bolivia) e incluso el curioso Cristo Roto de Aguascalientes, México; también podemos mencionar el Cristo del Otero en Palencia (España), el Cristo Rey de Lisboa, el Cristo Redentor de Maratea (Italia) o el Cristo Rey de Polonia. $\mathrm{Su}$ influencia, no obstante, ha llegado a sitios mucho más lejanos, como el Cristo de Vung Tau en Vietnam o el Cristo de Dili en Timor Oriental. Todos ellos presentan las mismas características generales de tamaño, ubicación y simbología.

El caso del Cristo Roto, en el que a diferencia del resto - siempre redentores -, Jesús aparece crucificado, nos sirve para establecer la diferencia fundamental entre sus representaciones vestido y aquéllas en las que se aprecia su desnudez casi completa, como es el caso: Cristo sólo viste el perizonium o paño de pureza. En el momento de la pasión y muerte se está poniendo de manifiesto su naturaleza humana y esto se representa mediante la exposición de su cuerpo humano desnudo. Por el contrario, cuando Cristo es presentado como Dios - esto es, cuando se pone de manifiesto su naturaleza divina -, aparece vestido, generalmente con túnica y manto.

El mismo modelo se aplica también a las estatuas colosales de Vírgenes, como la Virgen de la Paz en Venezuela o la Virgen del Socavón en Bolivia. La primera de ellas mide 46,72 m. de altura y es la estatua más alta de Suramérica y la representación de la Virgen María más grande del mundo entero. Le sigue muy de cerca la Virgen del Socavón, con 45,40 metros de altura ( 8,60 pertenecen a su base), situada a casi cuatro mil metros de altura; se trata de una construcción muy reciente, de 2013.

Vemos, pues, que el modelo del Coloso de Rodas, derribado en el 226 a.C., después de más de dos mil años continúa ejerciendo una poderosa influencia artística y

106. Antología Palatina VI 171. 
simbólica a la hora de realizar representaciones colosales en el mundo, sean estas de carácter laico o, como acabamos de ver, en el marco de la religión cristiana.

\section{Conclusiones}

A lo largo de estas páginas hemos podido constatar el modo en el que estas dos estatuas colosales, la de Zeus en Olimpia realizada por Fidias y la de Helios en Rodas, realizada por Cares de Lindos, se convirtieron en arquetipos para determinadas representaciones en torno a las ideas de divinidad, de majestad y de supremacía. Como hemos visto, el Zeus de Fidias sirvió de modelo para representaciones posteriores de esa misma divinidad en el ámbito greco-romano, e incluso para otros dioses en el marco del paganismo, así como para la nueva imagen de Cristo entronizado que surge cuando el Cristianismo se convierte en la religión oficial del Imperio. También sirvió de modelo para la representación de diversos emperadores romanos, comenzando por Augusto. Y aunque no sea objeto de este estudio, su imagen de poder y de majestad ha perdurado a lo largo de la historia del arte en ejemplos tan diversos como el Moisés, de Miguel Ángel, el Napoléon Emperador - Napoleón I en su trono imperial -, de Jean-Auguste Dominique Ingres, o en algunas estatuas de presidentes estadounidenses, como George Washington o Abraham Lincoln. Por su parte, el Coloso de Rodas también ha ejercido su influencia, aunque no de forma tan directa, primero sobre algunas estatuas colosales de emperadores romanos, y en el Renacimiento en algunos ejemplos aislados, como el David de Miguel Ángel, pero sólo cuando nos aproximamos a nuestra época contemporánea detectamos la renovación de su papel de modelo en la influencia ejercida sobre las estatuas colosales del presente, como las ya mencionadas estatuas de la Libertad en Nueva York o las de los Cristos y Vírgenes en el marco del Cristianismo, y también en algunas representaciones que pretenden la exaltación del héroe a modo de homenaje ejemplarizante, como en los casos del realismo heroico soviético o algunos memoriales o monumentos conmemorativos.

La postura sedente del Zeus, entronizado, sus atributos, sus ropajes, su pelo y su barba, incluso su expresión, y en el caso del Coloso, especialmente su tamaño y ubicación, como también su postura en algunos casos, han sido copiados, reinterpretados y generalizados en esas representaciones posteriores que los tomaron como modelos.

Aunque el Zeus sobrevivió mucho más tiempo que el Coloso, que apenas estuvo 66 años en pie, el legado de este último ha sido mucho más plástico y visual, debido a que no contó con descripciones literarias tan pormenorizadas como la que hizo Pausanias de la estatua de Fidias, por lo que su aspecto misterioso y legendario, unido a su tremendo tamaño, han inspirado numerosas representaciones pictóricas del mismo a lo largo de los siglos y diversas interpretaciones de figuras colosales en 
el cine, en el cómic, en los videojuegos, en la filatelia, etc. Pero sin duda, ninguna de las dos habría tenido la repercusión que hemos venido estudiando si no hubiesen estado incluidas en las listas iniciales de las Siete Maravillas de la Antigüedad y si no se hubiesen mantenido en la lista canónica que ha perdurado hasta nuestros días, algo especialmente evidente para el caso del Coloso. Desde este punto de vista, las listas de maravillas podrían ser consideradas como unos escaparates privilegiados, verdaderas pasarelas para estos modelos, que explicarían la enorme influencia que han tenido en la historia y, como hemos podido ver, también en la iconografía cristiana. 


\section{Anejos}

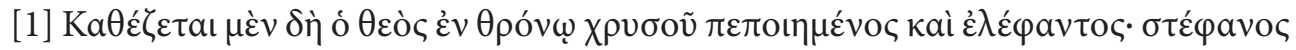

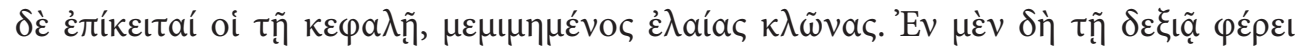

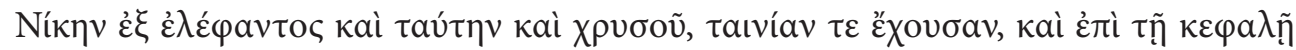

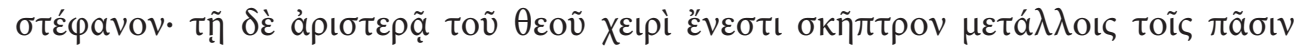

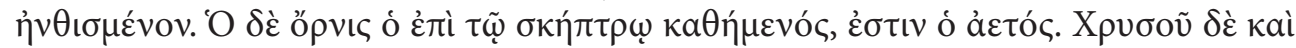

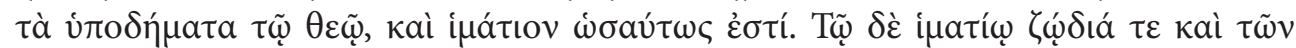

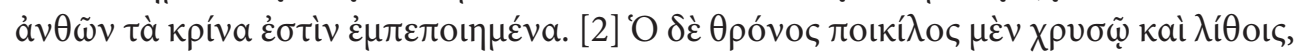

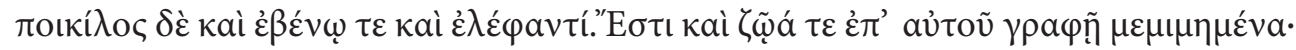

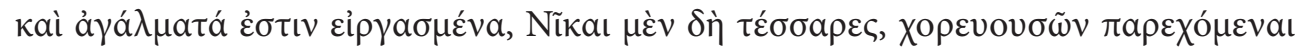

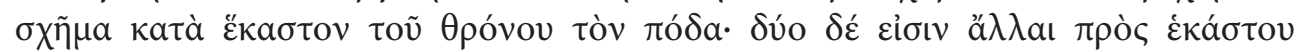

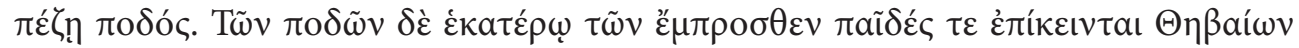

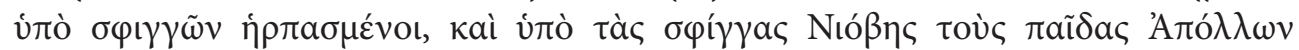

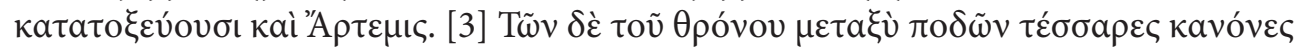

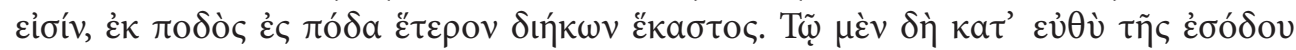

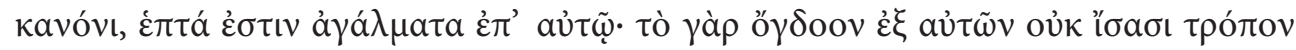

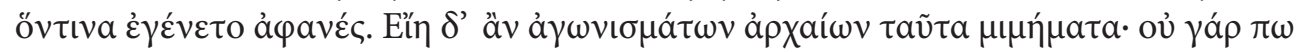

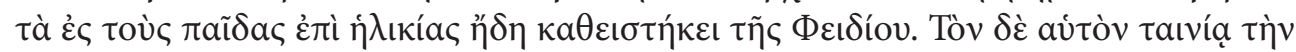

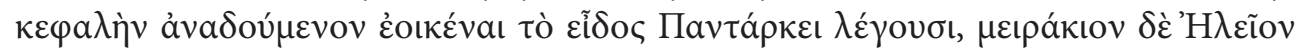

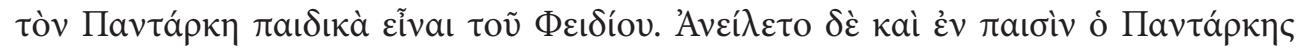

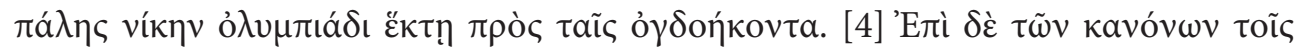

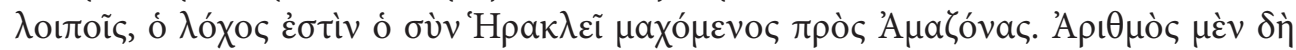

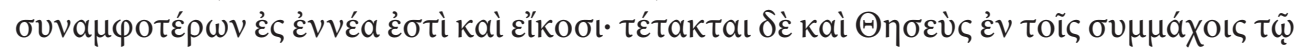

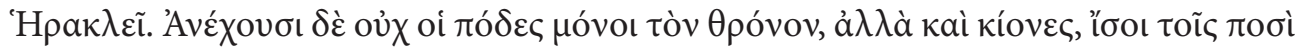

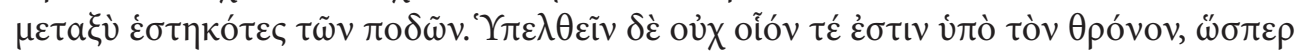

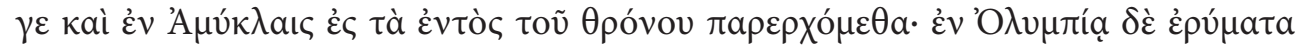

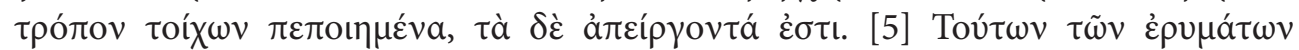

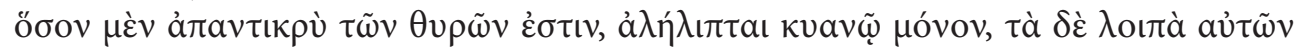

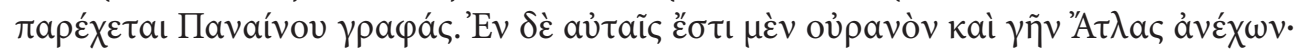

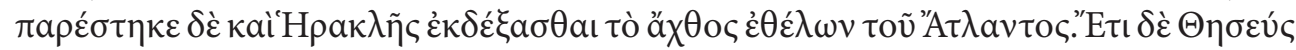

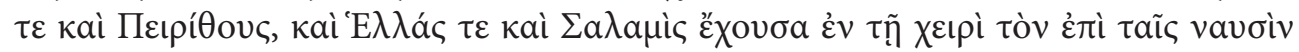

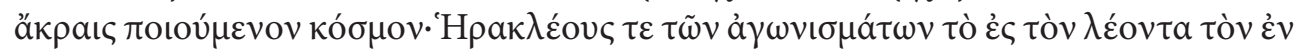

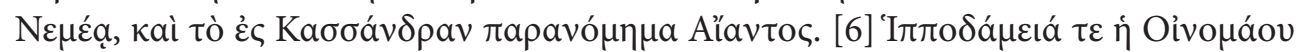

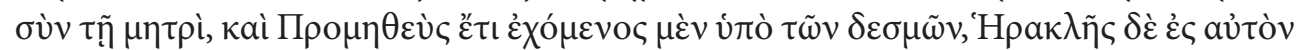

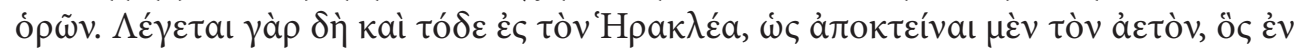

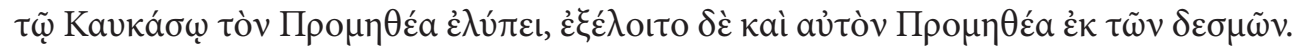




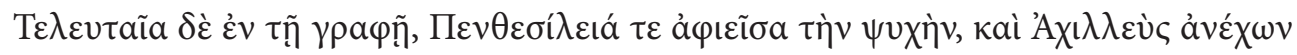

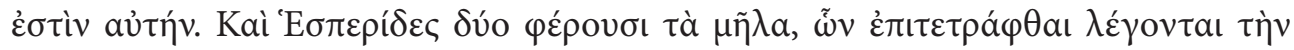

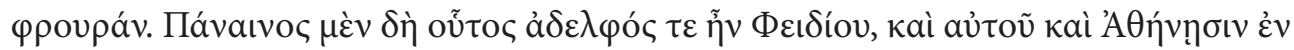

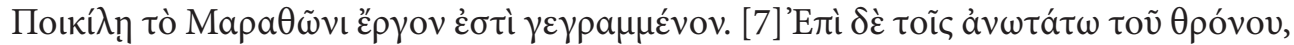

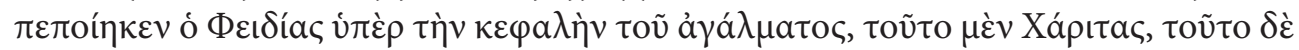

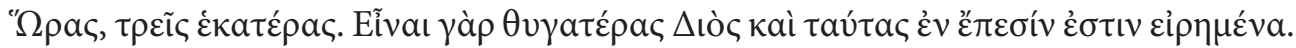
"O

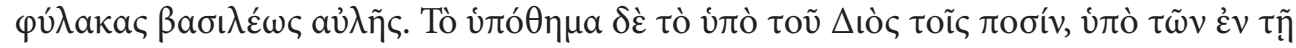

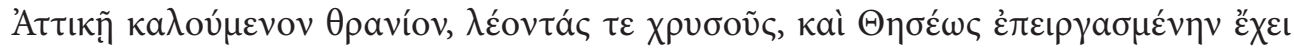

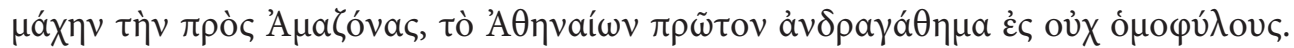

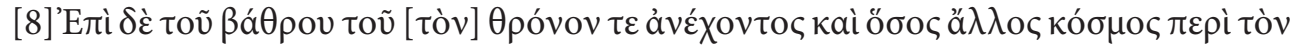

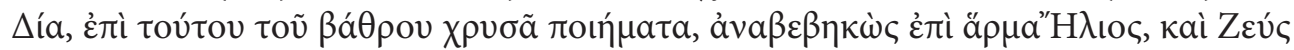

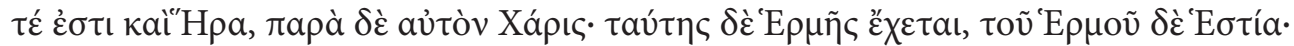

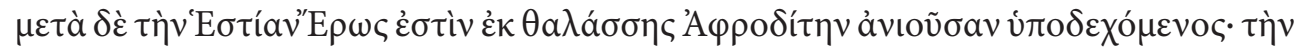

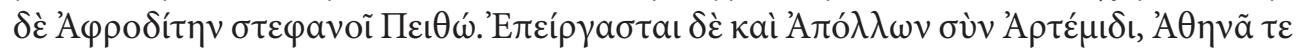

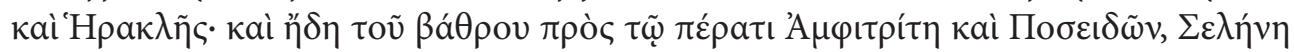

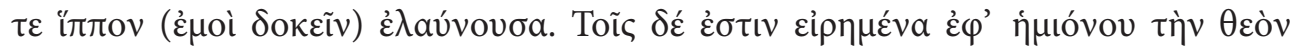

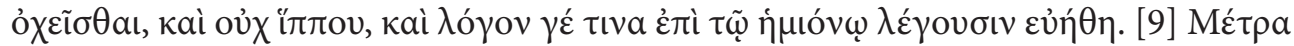

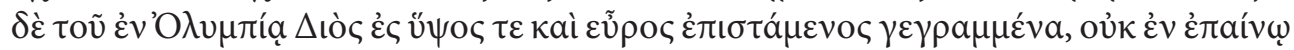

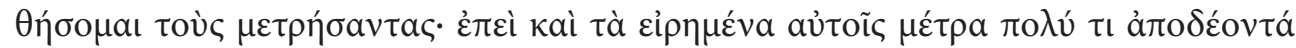

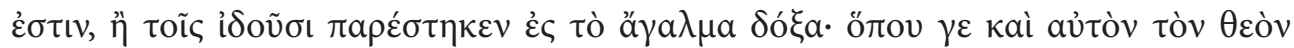

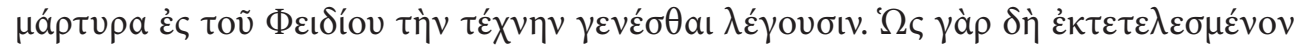

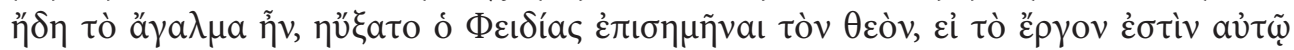

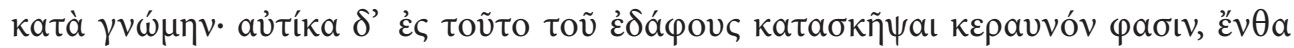

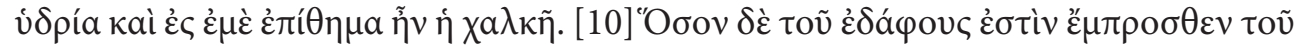

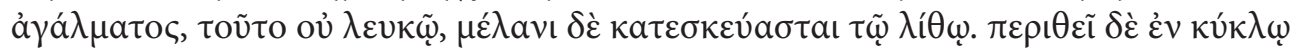

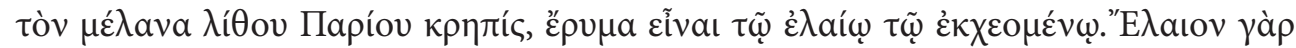

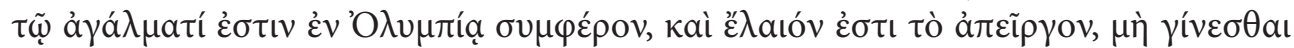

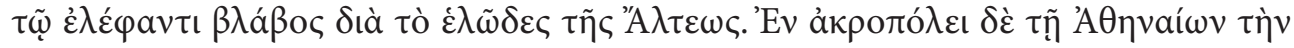

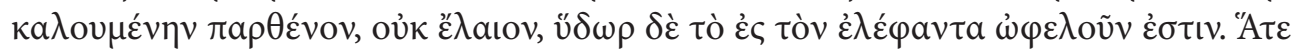

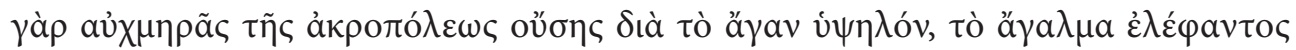

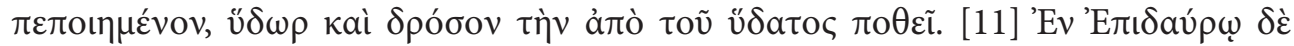

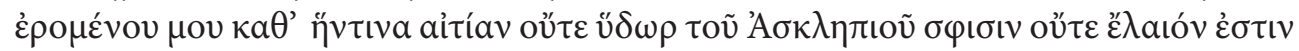

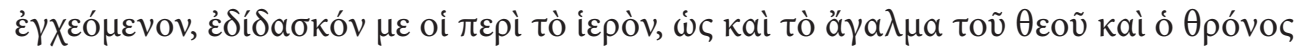

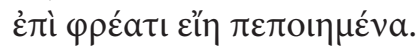

Pausanias, Descripción de Grecia V 11, 1-10. 


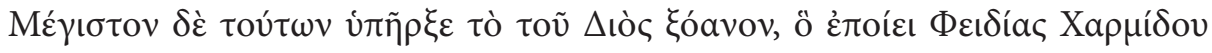

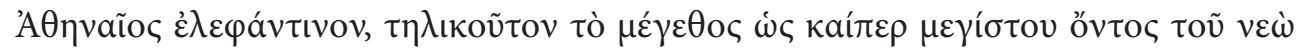

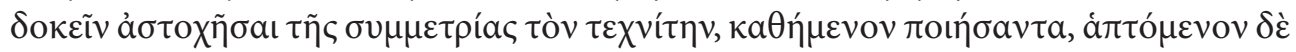

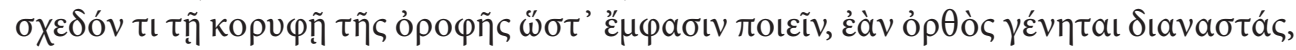

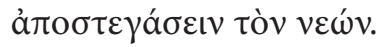

Estrabón, Geografía VIII 3, 30.

Phidias tamen dis quam hominibus efficiendis melior artifex creditur, in ebore vero longe citra aemulum vel si nihil nisi Minervam Athenis aut Olympium in Elide Iovem fecisset, cuius pulchritudo adiecisse aliquid etiam receptae religioni videtur, adeo maiestas operis deum aequavit. Ad veritatem Lysippum ac Praxitelen accessisse optime adfirmant: nam Demetrius tamquam nimius in ea reprehenditur, et fuit similitudinis quam pulchritudinis amantior.

Quintiliano, Institutio Oratoria XII 10, 9.

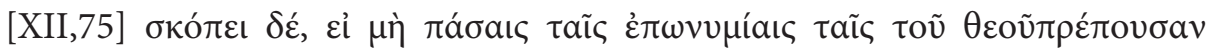

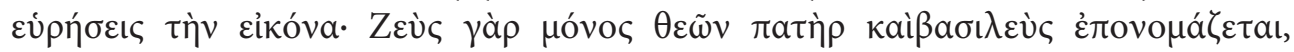

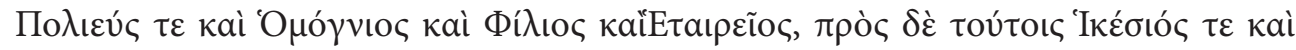

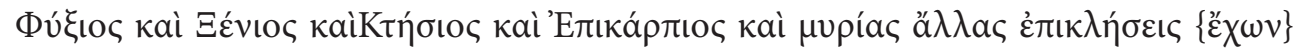

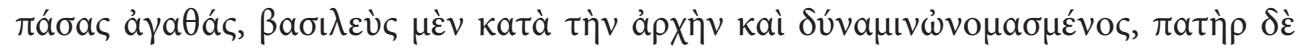

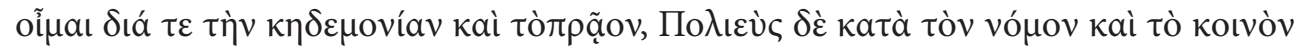

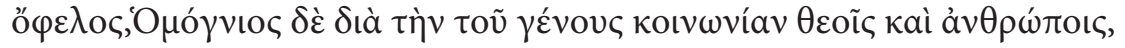

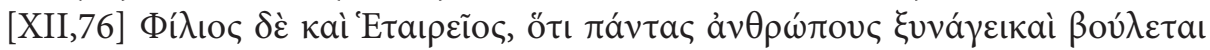

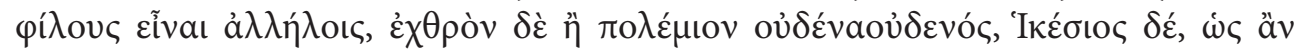

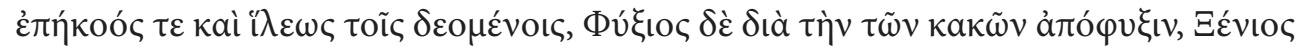

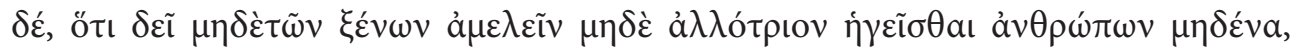

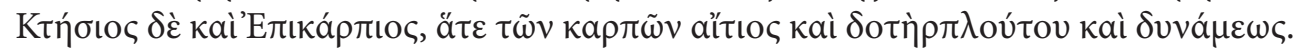

Dion de Prusa, Discursos XII 75-76.

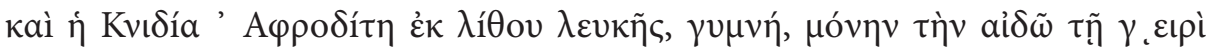

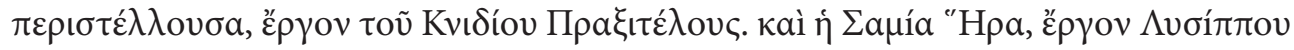

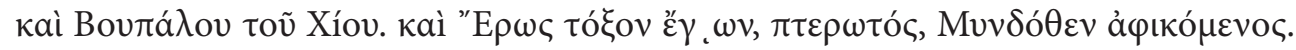

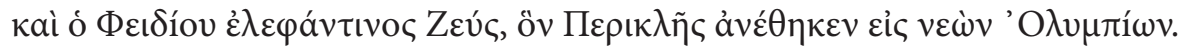

Jorge Cedreno, Synopsis Historion, I, Bonn, ed. I. Bekker, 1838, 564.

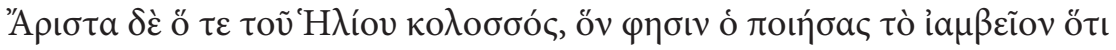

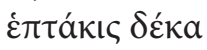

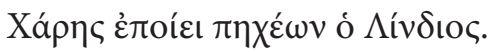




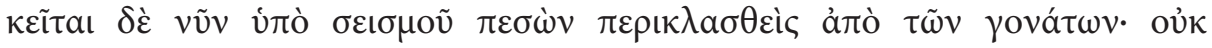

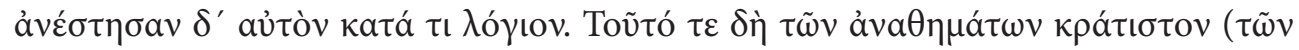

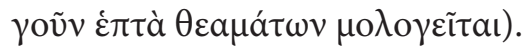

Estrabón, Geografía XIV 2, 5.

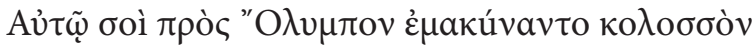

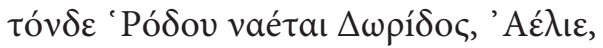

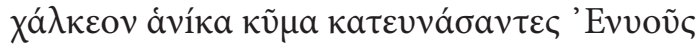

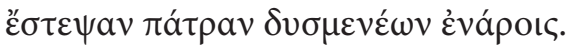

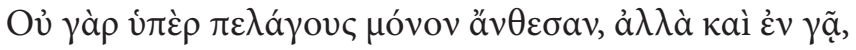

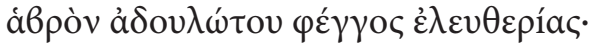

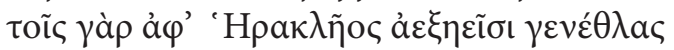

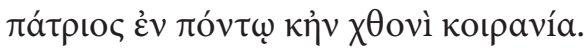

Antología Palatina VI 171. 


\section{Bibliografía}

Albertson, F.C. (2001). Zenodorus's Colossus of Nero. Memoirs of the American Academy in Rome, 46, pp. 95-118.

Almagro-Gorbea, M., Álvarez Martínez, J.M., Blázquez Martínez, J.M. y Rovira, S. (eds.) (2000). El Disco de Teodosio. Colección de Estudios del Gabinete de Antigüedades de la RAH n ${ }^{\circ}$ 5. Madrid. Real Academia de la Historia.

Ashton, R.H.J. (1988). Rhodian coinage and the Colossus. Revue numismatique, Serie 6a, 30, pp. $75-90$.

Auffarth, C. (2010). The materiality of God's Image: the Olympian Zeus and Ancient Christology. En Erskine y Bremmer, 2010, pp. 465-480.

Augé, L. (1878). Voyage aux Sept merveilles du monde. Paris: Librairie Hachette et C.

Badoud, N. (2012). L' image du Colosse de Rhodes. Monuments et mémoires de la fondation Eugène Piot, 91, pp. 5-39.

Barringer, J.M. (2011). The legacy of the Phidian Zeus at Olympia. En McWilliam, Puttock, Stevenson y Taraporewalla, 2011, pp. 61-71.

Barringer, J.M. (2015). The Changing Image of Zeus in Olympia. Archäologischer Anzeiger, 1, pp. 19-37.

Bassett, S.G. (2000). Excellent Offerings: The Lausos Collection in Constantinople. The Art Bulletin, 82.1, pp. 6-25.

Benveniste, É. (1932). A propos du Kolossos. Le sens du mot kolossos et les noms grecs de la statue. Revue de philologie, de littérature et d'histoire annciennes, serie 6, 3, pp. 118-135.

Betz, H.D. (2004). God Concept and Cultic Image: The Argument in Dio Chrysostom's Oratio 12 (Olympikos). Illinois Classical Studies, 29, pp. 131-142.

Bourke, G. (2011). The Statue of Zeus at Olympia and the Polis of the Eleians. En McWilliam, Puttock, Stevenson y Taraporewalla, 2011, pp. 9-22.

Breckenridge, J.D. (1959). The Numismatic Iconography of Justinian II (685-695, 705-711 AD.). Numismatics Notes and Monographs CXLIV. Nueva York: American Numismatic Society.

Brodersen, K. (1992). Reiseführer zu den Sieben Weltwundern: Philon von Byzanz und andere antike Texte. Frankfurt am Main y Leipzig: Inzel.

Brodersen, K. (2010). Las Siete Maravillas del mundo antiguo. Madrid: Alianza.

Burkert, W. (1988). The Meaning and Function of the Temple in Classical Greece. En Fox, 1988, pp. 27-47.

Burton, D. (2011). Nike, Dike and Zeus at Olympia. En McWilliam, Puttock, Stevenson y Taraporewalla, 2011, pp. 51-60.

Burton, D. (2015). The iconography of Pheidias' Zeus. Jahrbuch des Deutschen Archäologischen Instituts, 130, pp. 75-115.

Ceccarelli M. (ed.) (2004). International Symposium on History of Machines and Mechanisms. Dordrecht: Springer. 
Davison, C.C., Lundgreen, B. y and Waywell, G.B. (2009). Pheidias - the sculptures \& ancient sources. En Bulletin of the Institute of Classical Studies, vol.1, Supplement $n^{\circ} 105$.

Di Berardino, A. (1991). Diccionario Patrístico y de la Antigüedad Cristiana, vol. II. Salamanca: Sígueme.

Dickie, M.W. (1996). What Is a Kolossos and how Were Kolossoi Made in the Hellenistic Period. Greek, Roman and Byzantine Studies, 37, pp. 237-257.

Donati, A. y Gentili, G. (eds.) (2005). Costantino il Grande, La civiltà antica al bivio tra Occidente e Oriente. Milán: Silvana.

Dowden, K. (2006). Zeus. Londres y Nueva York: Routledge.

Errázuriz, L.H. y Balbontín, E.R. (1999). Imágenes de Cristo en el arte paleocristiano. Aisthesis, 32, pp. 105-124.

Erskine, A. y Bremmer, J. (eds.) (2010). The Gods of Ancient Greece: Identities and Transformations. Edimburgo: Edinburgh University Press.

Fittschen, K. y Zanker, P. (1985). Katalog der römischen Porträts in den Capitolinischen Museen und den anderen kommunalen Sammlungen der Stadt Rom, 2 vols. Mainz: von Zabern.

Fox, M.V. (ed.). (1988). The Temple in Society. Winona Lake: Eisenbrauns.

Freitag, K., Funke, P. y Haake, M. (eds.) (2006). Kult-Politik-Ethnos: Überregionale Heiligtümer im Spannungsfeld von Kult und Politik. Historia Einzelschriften CLXXXIX. Stuttgart.

Grabar, A. (1985). Las vías de la creación en la iconografía cristiana. Madrid: Alianza.

Green, J.R. (1978). The Wonders of the Ancient World. Sydney: Readers' Digest.

Guidoboni, E. et al. (1994). Catalogue of the Ancient Earthquakes in the Mediterranean Area up to the 10th Century. Roma: Instituto Nazionale di Geofisica.

Harrison, E.B. (1996). Pheidias. En Palagia y Pollit, 1996, pp. 16-65.

Heckenberg, K. (2011). The statue of Zeus at Olympia and the iconography of power and majesty in european, american and australian art. En McWilliam, Puttock, Stevenson y Taraporewalla, pp. 189-208.

Höpfner, W. (2003). Der Koloss von Rhodos und die Bauten des Helios. Mainz: von Zabern.

Holleaux, M. (1923). Polybe et le tremblement de terre de Rhodes. Revue des Études grecques, 36, pp. 490-498.

Holloway, R.R. (2004). Constantine \& Rome. New Haven: Yale University Press.

Karivieri, A. (2016). Divine or Human Images? Neoplatonic and Christian views on works of arts and aesthetics. Numen, 63.2-3, pp. 196-209.

Kircher, A. (1679). Turris Babel. Amsterdam: Sive Archontologia.

Kiilerich, B. (2015). The Barletta Colossus Revisited: The Methodological Challenges of an Enigmatic Statue. Acta ad archaeologiam et artium historiam pertinentia, n.s. 14, 28, pp. 55-72.

Kyrieleis, H. (2011). Olympia. Archäologie eines Heiligtums. Mainz: von Zabern.

Lapatin, K.D.S. (2001). Chryselephantine Statuary in the Ancient Mediterranean World. Oxford University Press.

Lapatin, K.D.S. (2010). New Statues for Old Gods. En Erskine y Bremmer, 2010, pp. 126-151. 
Lapatin, K.D.S. (2011). Representing Zeus. En McWilliam, Puttock, Stevenson y Taraporewalla, 2011, pp. 79-107.

Le Grand, L. (1984). Relation du pèlerinage de Nicolás de Martoni (1394-1395). Revue de l'Orient Latin, 3, pp. 566-669.

Lenski, N. (ed.) (2012). The Cambridge companion to the Age of Constantine. New York: Cambridge University Press.

Linke, B. (2006). Zeus als Gott der Ordnung. Religiöse Autorität im Spannungsfeld von überregionalen Überzeugungen und lokalen Kulten am Beispiel der Zeuskulte im archaischen Griechenland. En Freitag, Funke y Haake, 2006, pp. 89-120.

Mallet, A.M. (1683). Description de l'univers, II. Paris: Denys Thierry.

Manfredi, V.M. (2017). Las maravillas del mundo antiguo. Barcelona: Debolsillo.

Mango, C., Vickers, M. y Francis, E.D. (1992). The Palace of Lausus at Constantinople and its Collection of Ancient Statues. Journal of the History of Collections, 4.1, pp. 89-98.

Maryon, H. (1956). The Colossus of Rhodes. The Journal of Hellenic Studies, 76, pp. 68-86.

Mathews, T.F. (1993). The Clash of Gods. A Reinterpretation of Early Christian Art. Princeton NJ: Princeton University Press.

Mattusch, C.C., Donohue, A.A. y Brauer, A. (eds.) (2006). Common Ground: Archaeology, Art, Science, and Humanities. Proceedings of the XVIth International Congress of Classical Archaeology, Boston, August 2003. Oxford: Oxbow.

McWilliam, J., Puttock, S., Stevenson, T. y Taraporewalla, R. (eds.) (2011). The statue of Zeus at Olympia: new approaches, Newcastle upon Tyne: Cambridge Scholars Publishing.

Müller-Wiener, W. (1977). Bildlexikon zur Topographie Istanbuls. Byzantion, Konstantinupolis, Istanbul bis zum Beginn des 17. Jahrhundert. Tübingen: Wasmuth.

Nasrallah, L.S. (2010). Christian Responses to Roman Art and Architecture: The Second Century Church amid the Spaces of the Empire. Cambridge: Cambridge University Press.

Palagia, O. y Pollit, J.J. (eds.). (1998). Personal Styles in Greek Sculpture. Cambridge: Cambridge University Press.

Parisi Presicce, C. (2005). L'abbandono della moderazione. I ritratti di Costantino e della sua progenie. En Donati y Gentili, 2005, pp. 138-155.

Paynes, R. (1974). El Mundo del Arte. Barcelona: Martínez Roca

Platt, V. (2011). Facing the Gods. Epiphany and Representation in Greco-Roman Art, Literature and Religion. Cambridge University Press.

Pollitt, J.J. (1987). Arte y experiencia en la Grecia Clásica. Bilbao: Xarait.

Provoyeur, P. (1986). Bartholdi et la tradition colossale. En La Statue de la Liberté: l'exposition du centenaire, organisée par le Comité officiel franco-américain pour la célébration du centenaire de la statue de la Liberté et l'Union des arts décoratifs. París: Musée des arts décoratifs / Sélection du Reader's Digest.

Rieger, N.F. (2004). Engineering Aspects of the Collapse of the Colossus of Rhodes Statue. En Ceccarelli, 2004, pp. 69-85.

Safran, L. (2006). What Constantine Saw. Reflections on the Capitoline Colossus, Visuality, and Early Christian Studies. Millennium, 3, pp. 43-73. 
Sinn, U. (2004). Das Antike Olympia. Götter, Spiel und Kunst. Munich: C.H. Beck.

Sotomayor, M. (2003). El arte en el Cristianismo antiguo. En Sotomayor y Fernández Ubiña, 2003, pp. 869-904.

Sotomayor, M. y Fernández Ubiña, J. (eds.) (2003). Historia del Cristianismo. I. El mundo antiguo. Madrid: Trotta.

Stevenson, T. (2007). What happened to the Zeus of Olympia?. Ancient History Bulletin 21.14 , pp. $65-88$.

Stevenson, T. (2011). The fate of the Statue of Zeus at Olympia. En McWilliam, Puttock, Stevenson y Taraporewalla, 2011, pp. 155-167.

Stirling, L.M. (2005). The learned collector: Mythological Statuettes and Classical Taste in Late Antique Gaul. Ann Arbor: The University of Michigan Press.

Thevet, A. (1554). Cosmographie de Levant. Lyon: Jean de Tournes et Guillaume Gazeau.

Tigrini, O. (1574-1578). Li sette miracoli del' mondo, con grabados por Franz van Aelst. Roma.

Vedder, U. (2006). A Latin Grand Master, a Greek Philosopher and the Colossus of Rhodes. En Mattusch, Donohue y Brauer, 2006, pp. 151-153.

Vlizos, S. (1999). Der thronende Zeus. Eine Untersuchung zur statuarischen Ikonographie des Gottes in der spätklassischen und hellenistischen Kuns. Rahden: Leidorf.

Von Erlach, J.B.F. (1721). Entwurf einer historischen Architektur. Viena: Fischer von Erlach.

Zgoll, C. (2016). Der Koloss von Rom: Ein Weltwunder aus Worten. Gymnasium, 123.6, pp. 597-630. 